Summer 8-9-2021

\title{
Improving Mammography Rates Among the Hispanic Population: An Evidence-Based Project Utilizing a Promotora Intervention
}

\author{
Dawn Mirowski \\ University of St. Augustine for Health Sciences, dawn.mirowski@comcast.net
}

DOI: https://doi.org/10.46409/sr.FALG6532

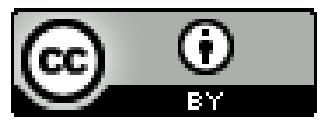

This work is licensed under a Creative Commons Attribution 4.0 License.

Follow this and additional works at: https://soar.usa.edu/scholprojects

Part of the Preventive Medicine Commons, Public Health and Community Nursing Commons, and the Women's Health Commons

\section{Recommended Citation}

Mirowski, D. (2021). Improving Mammography Rates Among the Hispanic Population: An Evidence-Based Project Utilizing a Promotora Intervention. [Doctoral project, University of St Augustine for Health Sciences].SOAR @ USA: Student Scholarly Projects Collection. https://doi.org/10.46409/sr.FALG6532

This Scholarly Project is brought to you for free and open access by the Student Research at SOAR @ USA. It has been accepted for inclusion in Student Scholarly Projects by an authorized administrator of SOAR @ USA. For more information, please contact soar@usa.edu, erobinson@usa.edu. 
Improving Mammography Rates Among the Hispanic Population: An Evidence-Based Project Utilizing a Promotora Intervention

\author{
Dawn Mirowski MSN, RN
}

School of Nursing, University of St. Augustine for Health Sciences

This Manuscript Partially Fulfills the Requirements for the

Doctor of Nursing Practice Program and is Approved by:

Theresa M. Pape PhD, RN, CNOR-E, CNE

Marjorie A. Kozlowski DNP, APRN, FNP-BC

Date of Final Approval: August 9, 2021 


\begin{abstract}
Practice Problem: Breast cancer is the leading cause of death in Hispanic women in the U.S., with mammography being the most effective means of reducing breast cancer mortality. Promotoras have been shown to improve health promotion, including mammography, among the Hispanic population.
\end{abstract}

PICOT: The PICOT question that guided this project was: In Hispanic women 40 years or older (P), how does the use of a promotora intervention (I), compared to no promotora intervention (C), affect mammography rates $(\mathrm{O})$ within an 8-week period $(\mathrm{T})$ ?

Evidence: Twenty-one studies that met the inclusion criteria supported the use of promotoras to improve mammography rates. Interventions included education and counseling, navigation assistance, providing a link to resources, and facilitating interaction with providers.

Intervention: A promotora was assigned to contact patients with a mammogram order to provide education, counseling, and other assistance needed.

Outcome: The intervention improved compliance with mammography rates by $37 \%$ over baseline. The results are clinically significant as the cost of the promotora intervention is minimal compared to the benefits of an early-stage diagnosis.

Conclusion: The implementation of this project was consistent with the research evidence supporting a promotora intervention to improve mammography rates in the Hispanic population. 


\section{Improving Mammography Rates Among the Hispanic \\ Population: An Evidence-Based Project Utilizing a Promotora \\ Intervention}

Cancer has surpassed heart disease as the leading cause of death in the Hispanic population (American Cancer Society [ACS], 2018). In Hispanic women, breast cancer is the most common type of cancer and the leading cause of cancer-related death in the U.S., with an incidence of $29 \%$ and a mortality rate of $16 \%$ (ACS, 2018; Luque et al., 2019). In 2016, the U.S. Census Bureau estimated that 57.5 million Americans (18\% of the population) identified as Hispanic or Latino, making them the largest and youngest minority group in the U.S. (ACS, 2018). Hispanics experience poorer health outcomes related to disparities such as language barriers, high levels of poverty, lack of health insurance, and quality of care (Aponte, 2017; League of United Latin American Citizens [LULAC], n.d.). As the population grows, the disparities will produce an increasing impact on the U.S. healthcare system. To overcome the health disparities, the LULAC (n.d.) stresses the importance of access to preventative care as well as linguistically and culturally competent care.

The purpose of this project was to implement an evidence-based clinical practice change with the goal of increasing mammography rates in Hispanic women at a clinic in the Midwestern U.S. This manuscript identifies the significance of the practice problem and includes a review of the scholarly evidence with practice themes and recommendations. The approach and methods were developed with consideration of the clinic's setting and stakeholders. The implementation plan consisted of the project objectives, schedule of activities, timeline, resources, budget, and dissemination of the results.

\section{Significance of the Practice Problem}


Research shows health disparities exist in breast cancer and mammography rates in the Hispanic population. The incidence rate of breast cancer in Hispanic women has increased $0.1 \%$ annually from 2006 to 2015 while remaining stable in non-Hispanic whites (ACS, 2018).

Compared to mammography rates of all racial and ethnic groups, Hispanic women consistently have the lowest rates (ACS, 2018; Martinez-Donate, 2009).

Studies demonstrate that mammography is the most effective means of reducing breast cancer mortality rates due to its ability to detect cancer at early stages when treatment may be more effective (ACS, 2018; Jadav et al., 2015; Jerome-D’Emilia, 2015; Simon et al., 2019). Preventive screening through mammography produces a direct impact on mortality rates and healthcare costs. Mammography is recommended yearly for women ages 45-54 and every 1-2 years for women 55 and older (ACS, 2018). The goal of Healthy People 2030 is for at least $77.1 \%$ of women to follow mammography recommendations (Office of Disease Prevention and Health Promotion, 2020).

Lower mammography rates contribute to the higher mortality rate due to later stage detection when tumors are larger and in more advanced stages (ACS, 2018; Larkey et al., 2012; Livaudais et al., 2010; Simon et al., 2016). In the U.S., Hispanic women with breast cancer are diagnosed at a local cancer stage $57 \%$ of the time versus $65 \%$ in non-Hispanic whites (ACS, 2018). If diagnosed in the local stage, the 5-year survival rate of breast cancer is $98 \%$ versus $25 \%$ if metastatic at the time of diagnosis (Blumen et al., 2016).

Studies show that the stage at diagnosis is the most important predictor of direct costs, with chemotherapy being the costliest (Sorensen et al., 2012; Wan et al., 2013). Cumulative treatment costs of treating breast cancer when diagnosed at Stage I is $\$ 29,724$, Stage II $\$ 39,322$ (32\% higher), Stage III \$57,827 (95\% higher), and Stage IV \$62,108 (109\% higher) (Sun et al., 
2018). Indirect costs to the patient and family related to absenteeism, short-term disability, premature mortality, and informal caregiving increase in later stages (Sorensen et al., 2012; Wan et al., 2013). Estimates of indirect costs after 5 -years of survivorship are over $\$ 2.9$ billion (Sorenson et al., 2012). In the first year of diagnosis, metastatic breast cancer (MBC) costs $\$ 3,000$ more in indirect costs than early-stage breast cancer (EBC), and families of MBC patients have 39.7\% higher indirect costs compared to EBC patients (Sorenson et al., 2012; Wan et al., 2013).

The healthcare system has an ethical responsibility to improve the health disparities of the Hispanic population. Disparities in healthcare access and cultural considerations impact the rates of mammography. Nationally, only $34 \%$ of uninsured Hispanics undergo mammography (ACS, 2018). Ethically, the quality of care should not vary based on race or ethnicity. Studies show that minorities often receive lower-quality healthcare (Bradley et al., 2001). Lower-income populations endure a greater incidence of cancer and a higher likelihood of diagnosis at a later stage with a greater risk of death (ACS, 2018). Barriers to mammography include the lack of health insurance and lower educational status (ACS, 2018).

Studies relate improved outcomes and quality of life to early detection with mammography (Janz et al., 2009). Low acculturation Hispanic women report a decreased quality of life related to advanced stage at diagnosis, the need for more intensive treatment, more side effects, and lower physical and emotional function (Janz et al., 2009). Culturally competent care through promotoras demonstrates effectiveness in addressing these disparities (Janz et al., 2009).

\section{PICOT Question}

In Hispanic women 40 years or older $(\mathrm{P})$, how does the use of a promotora intervention (I), compared to no promotora intervention $(\mathrm{C})$, affect mammography rates $(\mathrm{O})$ within an eight- 
week period (T)? The patient population of interest consisted of Hispanic female patients aged 40 years or older who have been ordered mammography screening by clinic practitioners within the identified timeframe of the project intervention. The promotora's assistance included culturally sensitive approaches through outreach and phone-based counseling. The mammography rates during the intervention timeframe were compared to baseline mammography rates, determined through data review and analysis, in the identical timeframe directly preceding the project intervention. The outcome of interest was the rate of mammography compliance during the project timeframe. Data were collected at least weekly throughout the intervention period.

\section{Evidence-Based Practice Framework}

Evidence-based practice (EBP) frameworks assist in identifying a clinical problem, searching for the best evidence, performing a critical appraisal of the evidence, developing a recommendation for action, implementing the intervention, and evaluating the recommendation (White et al., 2016). The model chosen for this project, the Johns Hopkins Nursing EBP Model (JHNEBP), consists of tools for use in a problem-solving approach to clinical decision-making (Johns Hopkins Medicine, 2017). The three-step process called PET stands for practice question, evidence, and translation. "The goal of the model is to ensure that the latest research findings and best practices are quickly and appropriately incorporated into patient care" (Johns Hopkins Medicine, 2017, p. 1).

The first step involves identifying the practice question (Johns Hopkins Medicine, 2017). This is accomplished by developing the team, defining the problem, and refining the EBP question. For this project, the problem was identified during an interdisciplinary team meeting 
with the stakeholders from the clinical site. Improving mammography rates was a primary goal for the clinic.

The second step involves the search, appraisal, and synthesis of evidence and concludes with recommendations based on the results (Johns Hopkins Medicine, 2017). This was done with an extensive search of evidence and further discussion with the team.

Finally, the translation phase determined the fit, feasibility, and appropriateness of the recommendation. The action plan was created, implemented, and evaluated with the results reported to the stakeholders and a plan made for sustainability (Johns Hopkins Medicine, 2017).

\section{Evidence Search Strategy}

A search was conducted using the University of St. Augustine's (USA) library, PubMed, Trip, CINAHL, and Cochrane databases. Using the PICOT question as a guide, five consecutive Boolean searches were performed using a combination of the following medical subject headings (MeSH) as keywords: Hispanic, Latina, promotora (es), community health workers, lay health advisors, breast cancer, mammogram, mammography, prevention, screening, and health promotion. The final Boolean search included the terms: promotora OR community health worker, AND mammogram OR mammography, AND Hispanic OR Latina. Due to the limited number of research articles, the filters were expanded beyond the last five years to include articles between 2000 and 2020. Other filters were set to include only peer-reviewed articles written in English.

The search resulted in 29 articles from USA, 28 from PubMed, seven from Trip, 11 from CINAHL, and one from Cochrane (Figure 1). After removing duplicate articles, a total of 31 articles were identified, and their abstracts were reviewed to select studies that satisfied the components of the PICOT question, specifically the use of promotora interventions to improve 
mammography in Hispanic women. A total of 13 articles were excluded for not meeting the inclusion criteria. Some common reasons for exclusion were that the study did not provide a promotora intervention, the population was too specific to a particular Hispanic demographic, or the outcome did not include mammography. After reviewing the full text and reference lists of the remaining 18 articles, six additional records were identified for inclusion, including an article outside the date parameters due to its relevance. A total of 24 articles met the criteria for an indepth review.

\section{Evidence Search Results}

An extensive review of the remaining 24 articles led to the exclusion of three articles as they did not fit the criteria for inclusion. The final 21 articles were reviewed to determine the strength of evidence using the level and quality standards outlined in the JHNEBP Model (Figure 1).

\section{Johns Hopkins Nursing Evidence-Based Practice (JHNEBP) Model}

The JHNEBP Evidence Level and Quality Guide and Research Evidence Appraisal Tool outlines criteria for determining the level and quality of evidence (Johns Hopkins Medicine, 2017). The appraisal tool includes an interactive version in which the user answers questions about the evidence to determine its level and quality. The guide lists the types of studies in each level ranging from $\mathrm{I}$ to $\mathrm{V}$ where level I evidence is the highest and includes randomized control trials and systematic reviews of randomized control trials. Level V is the weakest and consists of integrative and literature reviews. In each level, there are descriptors to determine the quality of the evidence in that level. The quality ratings are high, good, or low (Table 1).

As shown in Appendices A and B, all 21 articles are level I or II quantitative studies with the quality ranging from high to low. Appendix A summarizes the primary research evidence, 
and Appendix B summarizes the systematic reviews. The decision to include articles of lower quality was made due to the clinical significance and their value in support of the EBP project.

The three systematic reviews are level II, high-quality studies. Many of the studies in the reviews are included in the primary research evidence. Corcoran et al. (2010) sought to determine the effectiveness of various interventions in increasing mammography rates in Hispanic women. The authors included nine studies, with each consisting of educational and cultural components to the promotora intervention. Luque et al. (2019) studied educational interventions to increase mammography in Hispanic women. The five studies included in their review consisted of promotora-led education. The authors found that the promotoras may lessen the impact of barriers to mammography, such as low health literacy, knowledge deficits, and low awareness of the availability of screening services. Martinez-Donate (2009) reviewed the use of lay health advisors (LHAs) to promote breast and cervical cancer screening in Hispanic women. Of the four studies the authors reviewed, two found no significant effects, and two determined the LHAs were effective in increasing mammography rates.

\section{Themes with Practice Recommendations}

The improvement of mammography rates in Hispanic women begins with understanding the barriers specific to this population. The synthesis of evidence revealed themes addressing these barriers and the outcomes of various interventions.

\section{Barriers to Mammography}

The barriers to mammography in Hispanic women can be categorized into four areas: psychological and knowledge, logistics, cultural, and social and interpersonal (Miller et al., 2019). Psychological and knowledge-related barriers associate with low educational level, misconceptions regarding diseases, fear of pain or finding cancer, embarrassments, and the 
perceived lack of need (Hansen et al., 2005; Henderson et al., 2020; Jerome, 2015; Miller et al., 2018). Logistical barriers include access and cost of healthcare, lack of health insurance, low income, unemployment, lack of transportation, and time constraints due to social responsibilities of family, school, or work (Henderson et al., 2020; Jadav et al., 2015; Jerome, 2015; Miller et al., 2018). Mammography rates were affected by language barriers, immigration status, cultural norms that do not support cancer screening, and other misconceptions stemming from culture and beliefs (Jadav et al., 2015; Jerome, 2015; Miller et al., 2018). The social and interpersonal barriers include the lack of understanding of the U.S. healthcare system, discriminatory treatment, negative attitudes from healthcare providers, underrepresentation of Hispanics in healthcare fields, and the lack of provider recommendation (Jadav et al., 2015; Miller et al., 2018).

The 18 primary research studies that met the inclusion criteria for this project were analyzed to categorize themes considered for practice recommendations (Appendix C). Areas common to each study included the population, promotora intervention, and groups.

\section{Population}

The participants for each study found in the literature were Hispanic women and involved using a promotora-led intervention to improve mammography rates. The majority of the studies limited the age of the participants to 40 or older (11 of 18) and focused on low-income or un(under)-insured women (10 of 18).

\section{Promotora Intervention}

All but one study (Simon et al., 2019) contained an educational component to the intervention. Welsh et al. (2005) compared the effectiveness of educational printed materials to personalized education from promotoras among Medicaid-insured Hispanic women. The 
researchers found a marginal increase in the mammography rates using a promotora compared to printed materials alone. In 2007, Sauaia repeated this study with insured Hispanic women. The results showed a "significantly higher increase" in mammography rates.

Assisting participants through navigation was a common intervention by the promotora. Studies focused on telephone calls as reminders or to facilitate scheduling a mammogram (Coronado et al., 2016; Elder et al., 2017; Fernandez et al., 2009; Jandorf et al., 2014; Mojica et al., 2016), postcard reminders (Hunter et al., 2004), and assistance with scheduling (Coronado et al., 2016; Elder et al., 2017; Fernandez et al., 2009; Hunter et al., 2004; Jandorf et al., 2014; Mojica et al., 2016; Scheel et al., 2015; Simon et al., 2019). A study by Jandorf et al. (2014) found an increase in mammography compliance when assistance with scheduling, interpretation, and transportation was added to an educational component.

\section{Groups}

To address logistical barriers, studies included home visits (Coronado et al., 2016; Fernandez et al., 2009; Hunter et al., 2004; Nuño et al., 2011; Scheel et al., 2015), meetings at church (Elder et al., 2017; Lopez et al., 2006; Sauaia et al., 2007; Welsh et al., 2005), and multiple sites in the community, church, or home (Jandorf et al., 2014; Mojica et al., 2016).

Larkey et al. $(2006 ; 2012)$ emphasized social support among class members and, in both studies, determined that supporting social involvement improved mammography rates and was more cost-effective. Lopez et al. (2006) used a church-based approach, which improved participation in program attendance and provided social support. Using the social cognitive theory, Nuño et al. (2011) and Jandorf et al. (2014) focused on the interactions of people, their environments, and the psychosocial barriers of health behavior. The participants in the Nuño et al. (2011) study were twice as likely to have had a mammogram, and Jandorf et al. (2011) 
showed an increase in mammography. The benefits of a group setting were not significant in the study by Spalluto et al. (2019), in which the participants' satisfaction with care was higher, but mammography rates did not vary between the group and individual sessions.

\section{Practice Recommendations}

Promotoras share a common identity with the members of the community and provide education that is culturally relevant using the same language. Intimate knowledge and familiarity of the community may lower many barriers since promotoras are community members who are sought out naturally to provide advice, emotional support, and tangible aid. Promotoras can assist with outreach and appointment scheduling, provide patient navigation, link patients to resources, and facilitate interaction with providers.

Research related to the population of Hispanic women with the outcome of improved mammography rates supports the use of promotora-led interventions. The practice recommendation for this project was for the promotora to provide education, support, and navigation assistance with the goal of increasing compliance with mammography in the Hispanic population.

\section{Project Setting}

The setting for this project was a freestanding, not-for-profit community health clinic primarily serving low-income Spanish-speaking immigrant families in the Midwest area of the U.S. The clinic was started to provide quality, comprehensive healthcare and to meet the unique needs of the largely underserved immigrant community in this area.

The clinic staff includes the medical director, a nurse practitioner, a physician's assistant, a social worker, two medical assistants, a promotora, and support staff. The clinic provides culturally sensitive care, including 24-hour emergency availability, primary care, wellness 
education, mental health resources, nutritional counseling, and assistance navigating the healthcare system.

\section{Organizational Assessment}

During a brainstorming session with the medical director, nurse practitioner, office manager, and project manager, the need for improving mammography rates at the clinic was identified. There was a gap in care between the number of patients being ordered mammography and the number of patients obtaining mammograms. The final decision was made to address mammography rates based on the prioritization of needs and impact on patient outcomes. Along with the medical director and nurse practitioner, the primary stakeholders include the physician's assistant, medical assistants, promotora, the patients, and families.

A situational assessment was completed using a SWOT analysis (Figure 2). The clinic's strengths include a strong and dedicated group of leaders with a wealth of knowledge and experience, its system and organizational capacity, and its culture. Organizational weaknesses are primarily related to the availability of the staff, data infrastructure, and insufficient clinical processes and protocols. The opportunities for successful systems change included a strong culture of caring, teamwork, and trust between the staff and their patients. The threats to the project's success were the participants' health literacy, barriers related to time and transportation, and the availability of mammogram appointments.

The clinic is a front-line clinical microsystem with the goal of producing quality outcomes at the point of care. The improvement of mammography rates through a promotora intervention considers the specific needs of the patients, the culture of the clinic, and uses the skills and experience of the staff. The advantage of the social connections and cultural 
knowledge of the clinic's promotora aligned with processes and patterns of functioning already in place at the clinic.

\section{Change Theory}

This evidence-based practice change was implemented based on Rogers' Diffusion of Innovation model of change theory. The model identifies conditions that promote the adoption of an innovation and directs the focus of interactions to attributes that increase the likelihood of adoption (Mohammadi et al., 2018).

In the innovation-decision process, members of a social system will adopt or reject the innovation (Singer, n.d.). Rogers categorized the degree to which an individual adopts new ideas related to the other members of a system. Innovators work on the cutting edge and are excited by the possible benefits of innovation. Early adopters try out new ideas using the information provided by the innovators. Early majority adopters are thoughtful and careful but accept change quicker than average. Late majority adopters are skeptics who use new ideas only when it is used by the majority. Laggards are traditional people tied to doing things the old way and are often critical of new ideas (Orr, 2003; Singer, n.d.).

Readiness for change will improve when the stakeholders "understand, believe, and intend to change because of the perceived needs" (Al-Hussami et al., 2018, p. 355). The implementation of this EBP project required a change in the social system of the clinic. Providing a convincing argument in favor of the innovation to the opinion leader creates a tool the leader can use to communicate within the social system to affect the diffusion of the innovation (Orr, 2003). The project manager identified an opinion leader who was an early adopter and a well-informed decision-maker.

\section{Protection of Human Rights and Privacy}


Prior to implementing this project, approval was obtained from the Evidence-Based Practice Project Review Council at the University of St. Augustine for Health Sciences. The proposal was then reviewed and approved by the clinic's medical director and business manager. The project manager met with the interdisciplinary team members to outline the project details, review the intervention process diagram (Figure 3), and begin the training process.

The project participants' risks were minimal and included breach of confidentiality, participant lack of knowledge, and participant anxiety being contacted as part of a project. Data collection, analysis, and storage were the responsibility of the project manager. Data were deidentified, with each participant being assigned a code number. Hard copies of the data were stored in a locked file cabinet, and electronic data was stored using a password-protected computer.

\section{Project Overview}

The project objectives included the promotora intervention and the patient undergoing mammography screening. The goal for participants contacted by the promotora was $\geq 80 \%$ at week two, $\geq 85 \%$ at week four, $\geq 90 \%$ at week six, and $\geq 95 \%$ at week eight. The primary outcome goal was to increase the mammography rate by $20 \%$ over the baseline rate.

\section{Project Change Model}

The practice question, evidence, and translation plan were identified using the JHNEBP model for practice change. The clinic's practice issue was the need to improve the mammogram rates among their patients. The evidence from the literature supports the use of a promotorabased intervention. The translation into practice included defining the role of the promotora as a patient navigator based on the fit, feasibility, and appropriateness of the intervention for the clinic's patient population. 
The use of Rogers' Diffusion of Innovation Theory promoted stakeholder buy-in for the systems change. The project manager identified opinion leaders and early adopters who were more likely to try new ideas and encourage others to adopt and accept the change process. Areas of focus to improve the organization's readiness for change included the stakeholders' perceptions of their personal ability and the organization's capacity to make the changes successfully.

\section{Interprofessional Collaboration for Implementation}

Aligning and integrating each stakeholder's needs and interests creates a "transformative connection" within the interprofessional team (Harris et al., 2016, p. 101). The clinic is relatively small, with 20 employees, and there is a distinct feeling of the employees being a family with the common goal of improving their patients' health. This organizational culture facilitated agreement among the stakeholders throughout the project's implementation. Interprofessional teamwork and collaboration included every stakeholder, and bringing the team together for group meetings helped generate, share, and communicate ideas related to the project.

Effective interprofessional collaboration requires the use of a common language. The clinic is a Spanish-speaking organization, and the team included individuals from varying clinical backgrounds. The project manager focused on understanding the communication preferences of the Hispanic culture and the varying experiences of the team members.

\section{Activities, Timeline, and Resources}

The project began in March 2021 with the collection of baseline data and staff information sessions (Appendices D and E). The intervention was implemented for an eightweek period, and the findings were analyzed and summarized in May 2021. 
The primary resource needed was the time of the promotora for implementation of the intervention and recording the data. Other resources included the practitioner's time, office staff for record-keeping, and office supplies (Appendix F).

\section{Project Management Role}

To be effective, a team must remain focused on patient-centered goals, address any conflict openly and constructively, and share problem-solving responsibilities (Interprofessional Education Collaborative Expert Panel [IPEC], 2011). As a team leader, the project manager should value each member's potential contributions and increase teamwork support by understanding the teams' dynamics (IPEC, 2011). There should be a clear understanding of each member's role and responsibility, how the activities will be coordinated to achieve the goals, and how each member's role impacts the project's success (Bennett \& Gadin, 2012). An effective leader will communicate the vision that allows each member to recognize their contribution (Bennett \& Gadin, 2012). The project manager worked closely with the providers, medical assistants, and promotora to lead the intervention and provide frequent feedback.

\section{Results}

\section{Data Collection}

Data were collected through a review of the electronic medical record and communication with the clinic staff by the project manager and promotora. Baseline mammography rates were collected for an 8-week period directly preceding the project's implementation, and intervention data were collected weekly throughout the 8-week implementation period. The intervention consisted of the promotora contacting the participant within two days of the mammogram order and at least weekly, as needed, to provide education, support, and navigation assistance. 
The baseline group of 11 participants who were ordered a mammogram resulted in 8 participants obtaining a mammogram. The implementation group consisted of a total of 11 participants being ordered a mammogram, with all participants either scheduling or obtaining a mammogram.

\section{Data Collection Tools}

The data collection tool included the participants' demographic data, the mammogram order date, the participants' scheduling or completion of a mammogram, and a summary of the assistance provided by the promotora (Appendix G). Validity and reliability were ensured with the design of the tool to capture the intended information accurately.

\section{Comparison Data}

The pre-and post-intervention categorical data was collected and compared, including the outcome, process, balancing, financial, and sustainability measures (Appendix H). The goal of the outcome measure was to improve mammography compliance with a benchmark increase of $20 \%(n=2)$ at the project's conclusion. The goal was met with $100 \%(n=11)$ of the participants completing or scheduling a mammogram, which is a $37 \%(n=3)$ increase over the baseline.

\section{Statistical Analysis of Data}

Data were analyzed using Intellectus statistical software. The assumption of normality was assessed using the central limit theorem (CLT), which states that the mean of any random variable will be approximately normally distributed as sample size increases (Pituch \& Stevens, 2015). The sample size $\left(n_{\mathrm{s} 1}=11, n_{\mathrm{s} 2}=11\right)$ indicates that the CLT does not apply, and normality cannot be assumed. Therefore, the statistical results were interpreted carefully.

A two proportions $z$-test was conducted to examine whether there was a significant difference between the baseline and intervention groups. The result of the two proportions $z$-test 
was significant based on an alpha value of $0.05, z=-2.03, p=.042,95 \% \mathrm{CI}=[-0.54,-0.01]$, indicating the null hypothesis can be rejected. This suggests the proportion of the baseline group (0.73) was significantly different from the proportion of the intervention group (1.0), with the baseline group's results being significantly lower than the proportion of the intervention group. The $95 \%$ confidence interval for the difference between the proportions of the groups is -0.54 to -0.01 (Table 2).

\section{Clinical Significance}

The goal of this project was to achieve clinically significant results to improve the clinic's mammography rates and support the intervention's sustainability and dissemination. Clinical significance is the practical benefit measured by the magnitude of the relationship between the independent and outcome variables (El-Masri, 2016). Indicators of clinical significance include cost, patient values, and quality of life associated with the outcome (ElMasri, 2016). To demonstrate the clinical significance of the project's intervention, the sustainability measures outline the cost savings of a breast cancer diagnosis in the early stages compared to the financial and balancing measures of the cost to the clinic. The project's total costs were $\$ 1911$, and the estimated cost to sustain the intervention is $\$ 40$ per week (Appendices $\mathrm{F}$ and $\mathrm{H})$. The impact to the clinic related to cost and time is minimal compared to the benefits of diagnosing breast cancer in the early stages.

\section{Impact}

Among the Hispanic population, the use of promotoras is increasing as a go-between for the community and the health care system. While evidence supports the education, counseling, and navigation assistance provided by a promotora, the results of this project demonstrated that the primary need of all participants was with navigation assistance. One participant received 
counseling due to having a painful mammogram in the past. Another participant needed education about the importance of mammography screening before agreeing to schedule her mammogram. The remaining participants, who had not already had or scheduled their mammogram, were willing to schedule the mammogram but needed navigation assistance.

Evaluation of the results determined the primary practice problem to be a combination of a lack of a clinical process and patient follow-up after a mammogram is ordered. The recommendation for practice change was to develop a clinical protocol to ensure the proper referrals were made and communicated to the scheduling entities and to create a plan for the promotora to contact the patient to provide additional assistance, education, or support as needed.

The limitations of the project include the small number of participants, and the project occurred during the COVID-19 pandemic. The number of participants was small due to the clinic's patient population base and the decreased number of patients seen due to an unexpected absence of one of the providers. The COVID-19 pandemic affected the number of patients seen because one of the three providers was required to work remotely, making it impossible to perform the necessary physical examination before ordering a mammography screening. Despite these barriers, the number of participants from the baseline and intervention periods was the same.

\section{Sustainability}

The plan for sustainability involved a variety of efforts by the DNP student as the project manager. The clinic's promotora has agreed to continue the intervention. The staff has developed a clinical process and communication plan, beginning with the mammogram order and continuing through its completion. The nurse practitioner will continue to implement and evaluate the success of the practice change. 


\section{Dissemination}

The project manager met with the clinic's nurse practitioner to present the findings and develop a plan for sustainability and dissemination to the clinic staff. A poster presentation was given to the staff, which included the significance of the problem, the impact on the clinic and its patients, the evidence to support the promotora intervention, the recommended practice change, and the plan for sustainability.

The final paper will be uploaded to the University of St. Augustine for Health Sciences (USAHS) Library's Scholarship and Open Access Repository (SOAR). SOAR is a collection of the research and scholarly output from both faculty and students at USAHS. The National Association of Hispanic Nurses (NAHN) provides webinars for continuing education and holds an annual conference. An abstract for a poster presentation will be submitted for inclusion in the conference.

The manuscript will be submitted to the Hispanic Health Care International (HHCI), the official journal of NAHN. The journal is a peer-reviewed interdisciplinary resource for the "dissemination of information for clinical practice, education, research, and policy on issues concerning the Hispanic/Latino populations in the United States and other countries" (HHCI, 2020, Aims \& Scope section).

\section{Conclusion}

As previously stated, cancer has surpassed heart disease as the leading cause of death in the Hispanic population in the U.S., with breast cancer being the most common type (ACS, 2018). Disparities in healthcare access and cultural considerations impact the mammography rates among Hispanic women, who have consistently had the lowest screening rates of all racial and ethnic groups (ACS, 2018). 
Research studies support strategies for health promotion using culturally specific interventions designed to meet the needs of a population. Promotoras can assist Hispanic women through education and support, appointment scheduling, navigation assistance, providing a link to resources, and facilitating interaction with providers. The success of this project was in implementing the practice of a promotora intervention to increase mammography rates. The results further support research evidence showing that promotoras are effective in improving mammography rates in Hispanic women. 


\section{References}

Al-Hussami, M., Hammad, S., \& Alsoleihat, F. (2018). The influence of leadership behavior, organizational commitment, organizational support, subjective career success on organizational readiness for change in healthcare organizations. Leadership in Health Services, 31(4), 354-370. DOI:10.1108/LHS-06-2017-0031

American Cancer Society. (2018). Cancer facts \& figures for Hispanics/Latinos 2018-2020. https://www.cancer.org/content/dam/cancer-org/research/cancer-facts-andstatistics/cancer-facts-and-figures-for-hispanics-and-latinos/cancer-facts-and-figures-forhispanics-and-latinos-2018-2020.pdf

Aponte, J. (2017). Health disparities and Hispanics. Hispanic Health Care International, 15(2), 51. https://doi.org/10.1177/1540415317708513

Bennett, L. M., \& Gadlin, H. (2012). Collaboration and team science: From theory to practice. Journal of Investigative Medicine, 60(5), 769-775. DOI: 10.231/JIM.0b013e318250871d

Blumen, H., Fitch, K., \& Polkus, V. (2016). Comparison of treatment costs for breast cancer, by tumor stage and type of service. American Health \& Drug Benefits, 9(1), 23-32. https://pubmed.ncbi.nlm.nih.gov/27066193/

Bradley, C. J., Given, C. W., \& Roberts, C. (2001). Disparities in cancer diagnosis and survival. Cancer, 91(1), 178-188. https://doi.org/10.1002/1097-0142(20010101)91:1<178::AIDCNCR23>3.0.CO;2-S

Corcoran, J., Dattalo, P., \& Crowley, M. (2010). Interventions to increase mammography rates among U.S. Latinas: A systematic review. Journal of Women's Health, 19(7), 1281-1288. DOI: $10.1089 /$ jwh.2009.1621 
Coronado, G. D., Beresford, S. A., McLerran, D., Jimenez, R., Patrick, D. L., Ornelas, I., Bishop, S., Scheel, J. R., \& Thompson, B. (2016). Multilevel intervention raises Latina participation in mammography screening: Findings from ¡Fortaleza Latina! Cancer Epidemiology, Biomarkers \& Prevention, 25(4), 584-592. https://doi.org/10.1158/10559965.EPI-15-1246

Elder, J. P., Haughton, J., Perez, L. G., Martínez, M. E., De la Torre, C. L., Slymen, D. J., \& Arredondo, E. M. (2017). Promoting cancer screening among churchgoing Latinas: Fe en Acción/faith in action. Health Education Research, 32(2), 163-

173. https://doi.org/10.1093/her/cyx033

El-Masri, M. M. (2016). Statistical versus clinical significance in nursing research. Canadian Journal of Nursing Research, 48(2), 31-32. https://doi.org/10.1177/0844562116677895

Engelman, K. K., Cupertino, A. P., Daley, C. M., Long, T., Cully, A., Mayo, M. S., Ellerbeck, E. F., Geana, M. V., \& Greiner, A. (2011). Engaging diverse underserved communities to bridge the mammography divide. BMC Public Health, 11(47), 1-

17. https://doi.org/10.1186/1471-2458-11-47

Fernández, M. E., Gonzales, A., Tortolero-Luna, G., Williams, J., Saavedra-Embesi, M., Chan, W., \& Vernon, S. W. (2009). Effectiveness of Cultivando la Salud: A breast and cervical cancer screening promotion program for low-income Hispanic women. American Journal of Public Health, 99(5), 936-943. https://doi.org/10.2105/AJPH.2008.136713

Hansen, L. K., Feigl, P., Modiano, M. R., Lopez, J. A., Escobedo Sluder, S., Moinpour, C. M., Pauler, D. K., \& Meyskens, F. L. (2005). An educational program to increase cervical and breast cancer screening in Hispanic women: A Southwest Oncology Group 
study. Cancer Nursing, 28(1), 47-53. https://doi.org/10.1097/00002820-200501000-

$\underline{00007}$

Harris, J. L., Roussel, L., Dearman, C., \& Thomas, P. L. (2016). Project planning and management: A guide for nurses and interprofessional teams ( $2^{\text {nd }}$ ed.). Jones \& Bartlett Learning.

Henderson, L. M., O'Meara, E. S., Haas, J. S., Lee, C. I., Kerlikowske, K., Sprague, B. L., Alford-Teaster, J., \& Onega, T. (2020). The role of social determinants of health in selfreported access to health care among women undergoing screening mammography. Journal of Women's Health (Larchmentt). https://doi.org/10.1089/jwh.2019.8267

Hispanic Health Care International (HHCI) (2020). Manuscript submission guidelines. https://journals.sagepub.com/author-instructions/HCI

Hunter, J. B., de Zapien, J. G., Papenfuss, M., Fernandez, M. L., Meister, J., \& Giuliano, A. R. (2004). The impact of a promotora on increasing routine chronic disease prevention among women aged 40 and older at the U.S.-Mexico border. Health Education \& Behavior, 31(4), 18S-28S. https://doi.org/10.1177/1090198104266004

Interprofessional Education Collaborative Expert Panel (IPEC) (2011). Core competencies for interprofessional collaborative practice: Report of an expert panel. Interprofessional Education Collaborative https://www.aacom.org/docs/default-source/insideome/ccrpt0510-11.pdf?sfvrsn=77937f97_2

Jadav, S., Rajan, S. S., Abughosh, S., \& Sansgiry, S. S. (2015). The role of socioeconomic status and health care access in breast cancer screening compliance among Hispanics. Journal 
of Public Health Management \& Practice, 21(5), 467-

476. https://doi.org/10.1097/PHH.0000000000000235

Jandorf, L., Feldman-Hecht, M., Winkel, G., Thelemaque, L. D., Saad-Harfouche, F. G., Bursac, Z., Greene, P., \& Erwin, E. O. (2014). Increasing cancer screening for Latinas:

Examining the impact of health messages and navigation in a cluster-randomized study. Journal of Racial and Ethnic Health Disparities, 1(2), 85-100. http://dx.doi.org/10.1007/s40615-014-0022-6

Janz, N. K., Mujahid, M. S., Hawley, S. T., Griggs, J. J., Alderman, A., Hamilton, A. S., Graff, J., \& Katz, S. J. (2009). Racial/ethnic differences in quality of life after diagnosis of breast cancer. Journal of Cancer Survivorship, 3(4), 212-222. http://dx.doi.org/10.1007/s11764-009-0097-y

Jerome-D'Emilia, B. (2015). A systematic review of barriers and facilitators to mammography in Hispanic women. Journal of Transcultural Nursing, 26(1), 7382. https://doi.org/10.1177/1043659614530761

Johns Hopkins Medicine (2017). Center for evidence-based practice. https://www.hopkinsmedicine.org/evidence-based-practice/ijhn_2017_ebp.html

Koval, A. E., Riganti, A. A., \& Foley, K. L. (2006). CAPRELA (Cancer Prevention for Latinas): findings of a pilot study in Winston-Salem, Forsyth County. North Carolina Medical Journal, 67(1), 9-15. https://nciom.org/contemporary-issues-in-rural-healthcare/

Larkey, L. (2006). Las mujeres saludables: Reaching Latinas for breast, cervical and colorectal cancer prevention and screening. Journal of Community Health, 31(1), 6977. https://doi.org/10.1007/s10900-005-8190-2 
Larkey, L. K., Herman, P. M., Roe, D. J., Garcia, F., Lopez, A. M., Gonzalez, J., Perera, P. N., \& Saboda, K. (2012). A cancer screening intervention for underserved Latina women by lay educators. Journal of Women's Health, 21(5), 557566. https://doi.org/10.1089/jwh.2011.3087

League of United Latin American Citizens (LULAC) (n.d.). Latino health disparities. https://lulac.org/programs/health/health disparities/

Livaudais, J. C., Coronado, G. D., Espinoza, N., Islas, I., Ibarra, G., \& Thompson, B. (2010). Educating Hispanic women about breast cancer prevention: Evaluation of a home-based promotora-led intervention. Journal of Women's Health, 19(11), 20492056. https://doi.org/10.1089/jwh.2009.1733

Lopez, V. A., \& Castro, F. G. (2006). Participation and program outcomes in a church-based cancer prevention program for Hispanic women. Journal of Community Health, 31(4), 343-362. https://doi.org/10.1007/s10900-006-9016-6

Luque, J. S., Logan, A., Soulen, G., Armeson, K. E., Garrett, D. M., Davila, C. B., \& Ford, M. E. (2019). Systematic review of mammography screening educational interventions for Hispanic women in the United States. Journal of Cancer Education, 34(3), 412422. https://doi.org/10.1007/s13187-018-1321-0

Martínez-Donate, A. P. (2009). Using lay health advisors to promote breast and cervical cancer screening among Latinas: A review. Wisconsin Medical Journal, 108(5), 259-262. https://pubmed.ncbi.nlm.nih.gov/19743759/

Miller, B. C., Bowers, J. M., Payne, J. B., \& Moyer, A. (2019). Barriers to mammography screening among racial and ethnic minority women. Social Science \& Medicine, 239, 118. https://doi.org/10.1016/j.socscimed.2019.112494 
Mohammadi, M. M., Poursaberi, R., \& Salahshoor, M. R. (2018). Evaluating the adoption of evidence-based practice using Roger's diffusion of innovation theory: A model testing study. Health Promotion Perspectives, 8(1), 25-32. DOI: 10.15171/hpp.2018.03

Mojica, C. M., Morales-Campos, D. Y., Carmona, C. M., Ouyang, Y., \& Liang, Y. (2016). Breast, cervical, and colorectal cancer education and navigation: Results of a community health worker intervention. Health Promotion Practice, 17(3), 353-

363. https://doi.org/10.1177/1524839915603362

Navarro, A. M., Senn, K. L., McNicholas, L. J., Kaplan, R. M., Roppé, B., \& Campo, M. C. (1998). Por La Vida model intervention enhances use of cancer screening tests among Latinas. American Journal of Preventative Medicine, 15(1), 32-

41. https://doi.org/10.1016/s0749-3797(98)00023-3

Nuño, T., Martinez, M. E., Harris, R., \& García, F. (2011). A promotora-administered group education intervention to promote breast and cervical cancer screening in a rural community along the U.S.-Mexico border: A randomized controlled trial. Cancer Causes \& Control, 22(3), 367-374. https://doi.org/10.1007/s10552-010-9705-4

Office of Disease Prevention and Health Promotion. (2020). Increase the proportion of females who get screened for breast cancer-C05. https://health.gov/healthypeople/objectives-anddata/browse-objectives/cancer/increase-proportion-females-who-get-screened-breast$\underline{\text { cancer-c-05 }}$

Orr, G. (2003, March 18). Diffusion of innovations by Everett Rogers. https://web.stanford.edu/class/symbsys205/Diffusion\%20of\%20Innovations.htm

Pituch, K. A., \& Stevens, J. P. (2015). Applied multivariate statistics for the social sciences $\left(6^{\text {th }}\right.$ ed.). Routledge Academic. https://doi.org/10.4324/9781315814919 
Sauaia, A., Min, S. J., Lack, D., Apodaca, C., Osuna, D., Stowe, A., MGinnis, G. F., Latts, L. M., \& Byers, T. (2007). Church-based breast cancer screening education: Impact of two approaches on Latinas enrolled in public and private health insurance plans. Preventing Chronic Disease, 4(4), A99. https://www.ncbi.nlm.nih.gov/pmc/articles/PMC2099296/

Savas, L. S., Heredia, N. I., Coan, S. P., \& Fernandez, M. E. (2018). Effectiveness of a community health worker-delivered intervention to increase breast and cervical cancer screening among medically underserved Hispanics. Journal of Global Oncology, 4 (Supplement 2), 19s. DOI: 10.1200/jgo.18.70400

Scheel, J. R., Molina, Y., Briant, K. J., Ibarra, G., Lehman, C. D., \& Thompson, B. (2015). Latinas' mammography intention following a home-based promotores-led intervention. Journal of Community Health, 40(6), 1185-

1192. https://doi.org/10.1007/s10900-015-0046-9

Simon, M. A., O'Brian, C. A., Kanoon, J. M., Venegas, A., Ignoffo, S., Picard, C., Allgood, K. L., Tom, L., \& Margellos-Anast, H. (2019). Leveraging an implementation science framework to adapt and scale a patient navigator intervention to improve mammography screening outreach in a new community. Journal of Cancer Education, 35(3), 530537. https://doi.org/10.1007/s13187-019-01492-8

Singer, L. (n.d.) On the diffusion of innovations: How new ideas spread. https://leif.me/on-thediffusion-of-innovations-how-new-ideas-spread/

Sorensen, S. V., Goh, J. W., Pan, F., Chen, C., Yardley, D., Martin, M., Knopf, K., Benedict, A., Giorgetti, C., \& Iyer, S. (2012). Incidence-based cost-of-illness model for metastatic breast cancer in the United States. International Journal of Technology Assessment in Health Care, 28(1), 12-21. DOI: 10.1017/S026646231100064X 
Spalluto, L. B., Audet, C. M., Murry, V. M., Barajas, C. P., Beard, K. R., Campbell, T. T., Thomas, D., Sanderson, M., Yu, C., Dittus, R. S., Roumie, C. L., Wilkins, C. H., \& Shrubsole, M. J. (2019). Group versus individual educational sessions with a promotora and Hispanic/Latina women's satisfaction with care in the screening mammography setting: A randomized controlled trial. American Journal of Roentgenology, 213(5), 1029-1036. https://doi.org/10.2214/AJR.19.21516

Sun, L., Legood, R., Dos-Santos-Silva, I., Gaiha, S. M., \& Sadique, Z. (2018). Global treatment costs of breast cancer by stage: A systematic review. PLoS One, 13(11), e0207993. https://doi.org/10.1371/journal.pone.0207993

Wan, Y., Gao, X., Mehta, S., Wang, Z., Faria, C., \& Schwartzberg, L. (2013). Indirect costs associated with metastatic breast cancer. Journal of Medical Economics, 16(10), 11691178. https://doi.org/10.3111/13696998.2013.826228

Welsh, A. L., Sauaia, A., Jacobellis, J., Min, S. J., \& Byers, T. (2005). The effect of two churchbased interventions on breast cancer screening rates among Medicaid-insured Latinas. Preventing Chronic Disease, 2(4), A07. https://pubmed.ncbi.nlm.nih.gov/16164811/

White, K. M., Dudley-Brown, S., \& Terhaar, M. F. (2016). Translation of evidence into nursing and health care ( $2^{\text {nd }}$ ed.). Springer Publishing Company. 


\section{Table 1}

Johns Hopkins Nursing Evidence-Based Practice Evidence Level and Quality Guide

Evidence Levels

Level I (experimental/RCT, explanatory

mixed method with level I quaNtitative studies, SR of RCTs)

Level II (Quasi-experimental, explanatory mixed method with level II quaNtitative studies, SR of RCTs and quasi-experimental or quasi-experimental studies only)

Level III (Nonexperimental, SR combination of RCTs, quasi and nonexperimental, or nonexperimental studies only)

Level IV (opinion of respected authorities, expert committees, consensus panels)

Level V (experiential and non-research evidence)

\section{QuaNtitative Quality Ratings}

A (high quality): Consistent, generalizable results; sufficient sample size for the study design; adequate control; definitive conclusions; consistent recommendations based on comprehensive literature review that includes thorough reference to scientific evidence.

B (good quality): Reasonably consistent results; sufficient sample size for the study design; some control, fairly definitive conclusions; reasonably consistent recommendations based on fairly comprehensive literature review that includes some reference to scientific evidence.

C (low quality): Little evidence with inconsistent results; insufficient sample size for the study design; conclusions cannot be drawn.

Legend: SR, Systematic Review; RCT, Randomized Control Trial

From: Johns Hopkins Medicine (2017). Center for evidence-based practice. https://www.hopkinsmedicine.org/evidence-based-practice/ijhn_2017_ebp.html 


\section{Table 2}

Two Proportions z-Test for the Difference between the Baseline Group and Intervention Group

\begin{tabular}{lrrrrr}
\hline Samples & Responses & $n$ & Proportion & $S D$ & $S E$ \\
\hline Baseline Group & 8 & 11 & 0.73 & 0.45 & 0.13 \\
Intervention Group & 11 & 11 & 1 & 0.00 & 0.00 \\
\hline
\end{tabular}

Note. $z=-2.03, p=.042,95 \% \mathrm{CI}:[-0.54,-0.01]$ 


\section{Figure 1}

PRISMA 2009 Flow Diagram

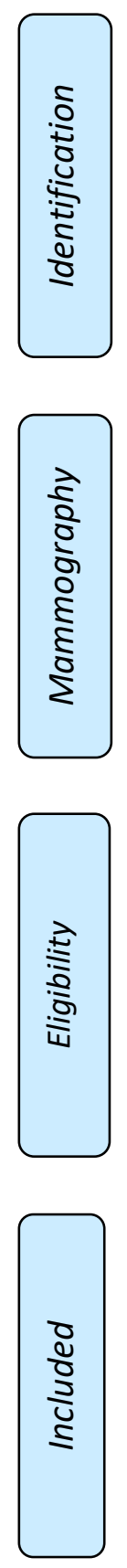

Records identified through database searching $(\mathrm{n}=76)$
Additional records identified through other sources

$$
(\mathrm{n}=6)
$$

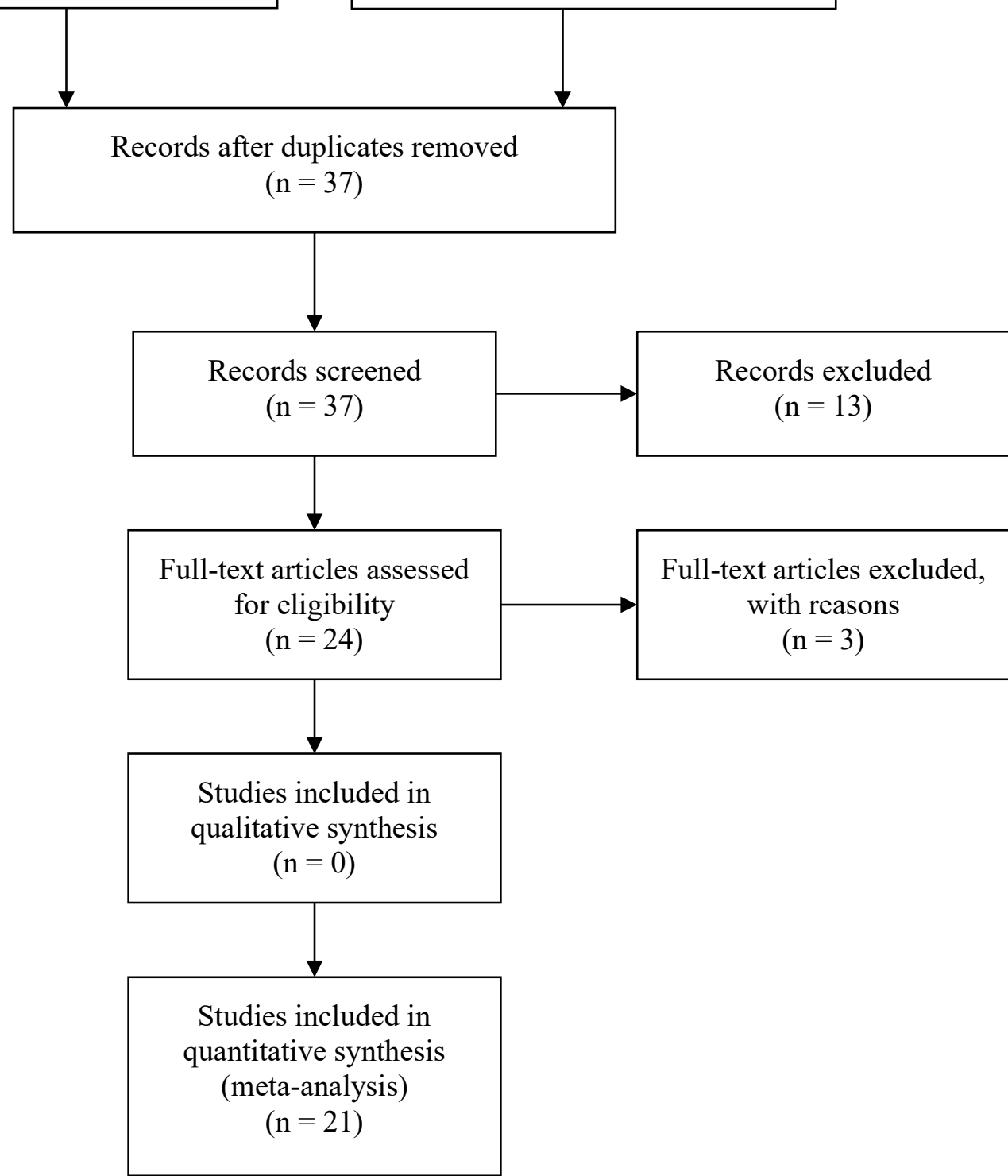

From: Moher, D., Liberati, A., Tetzlaff, J., \& Altman, D.G., The PRISMA Group (2009). Preferred reporting items for systematic reviews and meta-analyses: The PRISMA statement. PLoS Med 6(7): e1000097. doi:10.1371/journal.pmed1000097 
Figure 2

SWOT Analysis

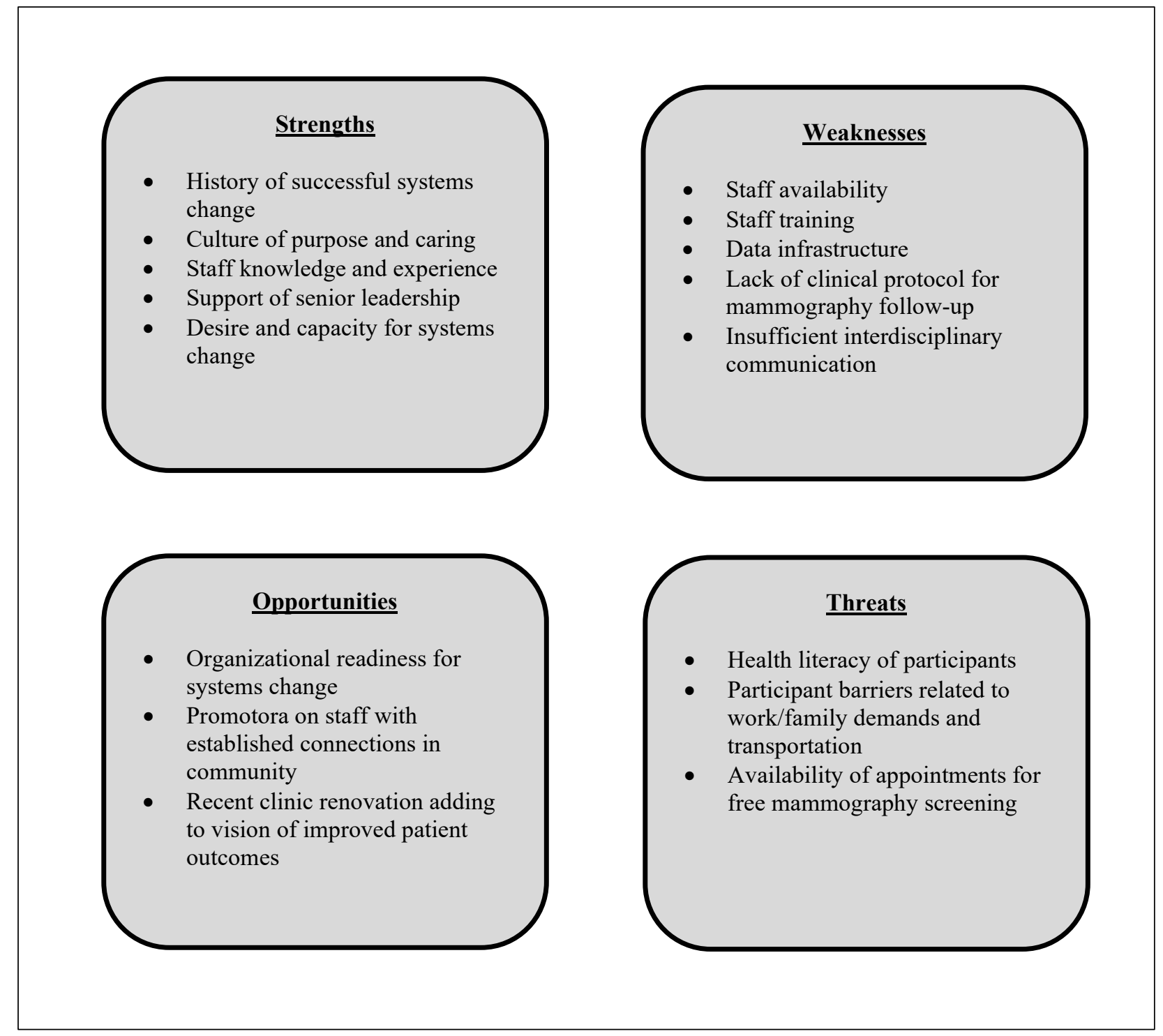




\section{Figure 3}

Mammogram Process Diagram

\section{Mammogram Screening Promotora Intervention}

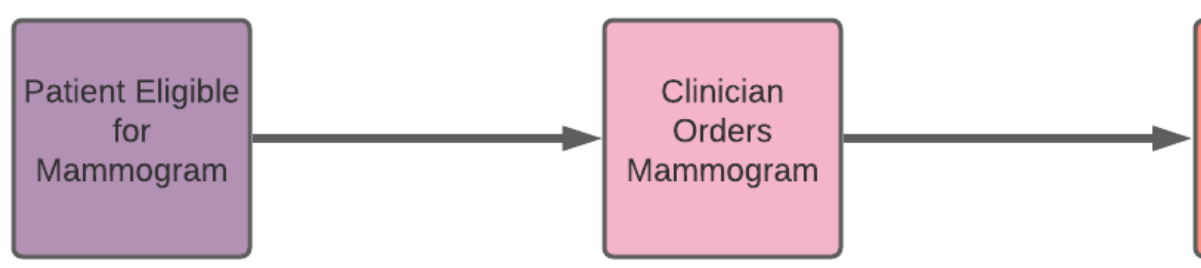

Clinician

Messages

Promotora in

EMR

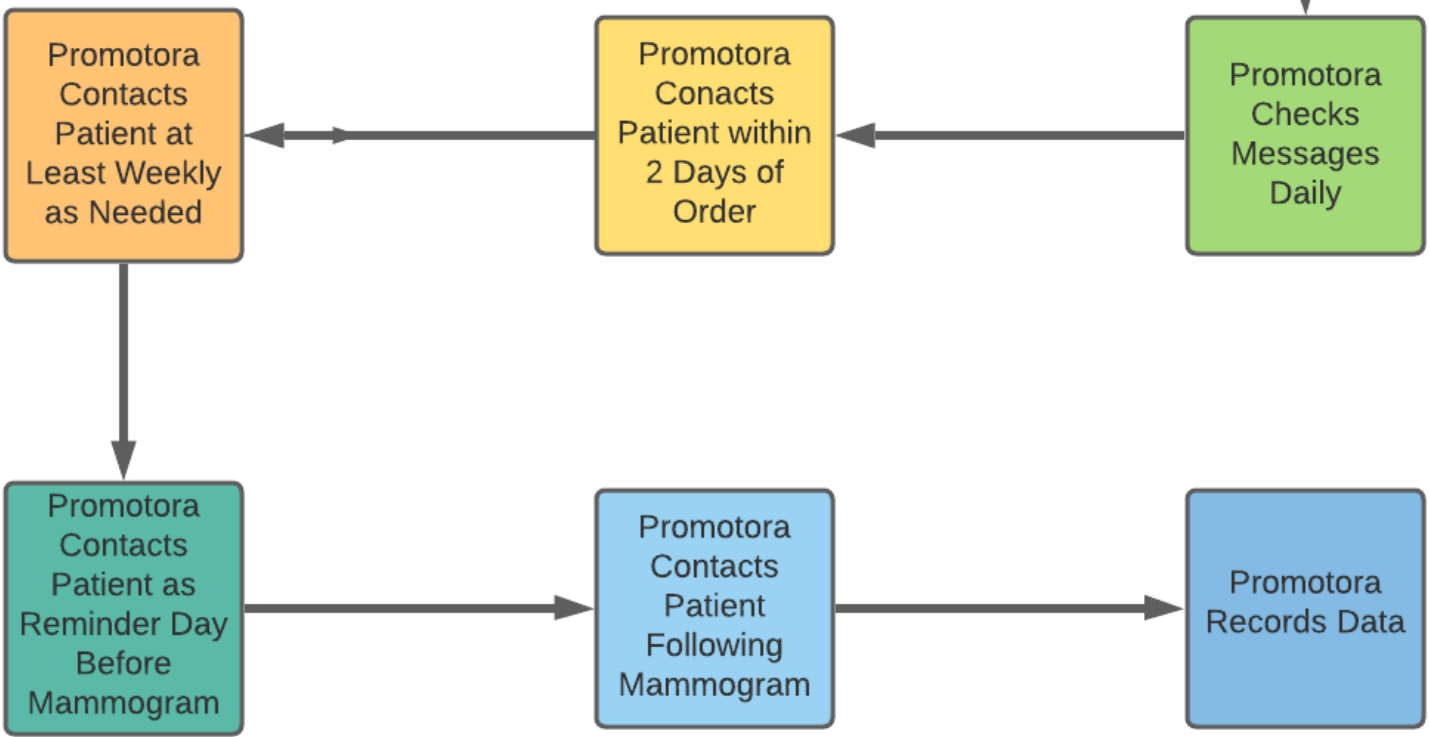




\section{Appendix A}

\section{Summary of Primary Research Evidence}

\begin{tabular}{|c|c|c|c|c|c|}
\hline Citation & $\begin{array}{l}\text { Design, } \\
\text { Level } \\
\text { Quality } \\
\text { Grade }\end{array}$ & $\begin{array}{c}\text { Sample } \\
\text { Sample size }\end{array}$ & \begin{tabular}{|l} 
Intervention \\
Comparison \\
Research tools \\
\end{tabular} & Outcome Definition & $\begin{array}{l}\text { Usefulness } \\
\text { Results } \\
\text { Key Findings }\end{array}$ \\
\hline $\begin{array}{l}\text { Coronado et } \\
\text { al., } 2016\end{array}$ & RCT, I A & $\begin{array}{l}\text { Hispanic } \\
539 \text { participants } \\
(278 \\
\text { intervention, } \\
261 \text { control })\end{array}$ & $\begin{array}{l}\text { Randomized to promotora interventions versus standard care } \\
\text { (control) } \\
\text { Promotora home visits and telephone calls } \\
\text { Mobile mammography unit } \\
\text { Intent-to-treat analysis } \\
\text { Analyzed effect by clinic assignment and intervention } \\
\text { condition and adjusted for confounding characteristics }\end{array}$ & $\begin{array}{l}\text { Mammography } \\
\text { screening }\end{array}$ & $\begin{array}{l}\text { Mammogram rates } 19.6 \% \\
\text { intervention group vs } 11 \% \\
\text { in control group }\end{array}$ \\
\hline $\begin{array}{l}\text { Elder et al., } \\
2017\end{array}$ & RCT, I A & $\begin{array}{l}\text { Hispanic } \\
\text { Churchgoing } \\
436 \text { participants }\end{array}$ & $\begin{array}{l}\text { Groups randomized to either cancer screening or physical } \\
\text { activity intervention } \\
\text { Promotora led 6-week class and called each participant to } \\
\text { evaluate barriers to screening and establish goals for } \\
\text { screening } \\
\text { Promotora accompanied participant to appointment if needed } \\
\text { Acculturation scores using (BAS) } \\
\text { Esperanza y Vida questionnaire to assess cancer knowledge }\end{array}$ & $\begin{array}{l}\text { Compliance with } \\
\text { mammogram screening }\end{array}$ & $\begin{array}{l}\text { Mammogram compliance } \\
\text { increased from } 44 \% \text { to } 61 \% \\
\text { in cancer screening } \\
\text { intervention but decreased } \\
\text { in physical activity group }\end{array}$ \\
\hline $\begin{array}{l}\text { Fernandez et } \\
\text { al., } 2009\end{array}$ & $\begin{array}{l}\text { Quasi- } \\
\text { experiment } \\
\text { al, II A }\end{array}$ & $\begin{array}{l}\text { Hispanic } \\
\text { Low-income } \\
207 \\
\text { intervention } \\
257 \text { control }\end{array}$ & $\begin{array}{l}\text { Lay health workers education program with telephone } \\
\text { follow up } 2 \text { weeks after } \\
\text { BAS to measure acculturation } \\
\text { Psychosocial constructs with 5-point Linkert-type scales } \\
\text { Intent-to-treat analysis for screening completion }\end{array}$ & $\begin{array}{l}\text { Improved } \\
\text { mammography screening }\end{array}$ & $\begin{array}{l}\text { Mammogram rate increased } \\
\text { from } 29.9 \% \text { to } 40.8 \% \\
\text { Intervention more effective } \\
\text { with low levels of } \\
\text { acculturation } \\
\text { Increased perceived } \\
\text { susceptibility, survivability, } \\
\text { and benefits to } \\
\text { mammography }\end{array}$ \\
\hline $\begin{array}{l}\text { Hansen et al., } \\
2005\end{array}$ & $\mathrm{RCT}, \mathrm{II} \mathrm{C}$ & $\begin{array}{l}\text { Hispanic } \\
141 \text { participants } \\
\text { Aged } 22-69\end{array}$ & $\begin{array}{l}\text { Trained Hispanic cancer survivors to act as promotoras who } \\
\text { provided information and encouraged screening to family } \\
\text { and social contacts }\end{array}$ & $\begin{array}{l}\text { Assess feasibility of } \\
\text { training Hispanic cancer } \\
\text { survivors to act as } \\
\text { promotoras and } \\
\text { determine if they are } \\
\text { willing to contact family }\end{array}$ & $\begin{array}{l}29 \text { of } 50 \text { received } \\
\text { mammogram } \\
\text { Unclear how many women } \\
\text { were aged } 40 \text { or older }\end{array}$ \\
\hline
\end{tabular}




\begin{tabular}{|c|c|c|c|c|c|}
\hline & & & & $\begin{array}{l}\text { and social contacts to } \\
\text { provide teaching } \\
\text { Does intervention } \\
\text { increase screening } \\
\end{array}$ & \\
\hline $\begin{array}{l}\text { Hunter et al., } \\
2004\end{array}$ & RCT, I A & $\begin{array}{l}\text { Hispanic } \\
\text { Uninsured } \\
\text { Rural } \\
101 \text { participants }\end{array}$ & $\begin{array}{l}\text { Offered free comprehensive physical exam } \\
\text { CHW visit versus post card reminder for exam } \\
\text { Fisher's exact test to assess differences in distribution in } \\
\text { groups } \\
\text { Intent-to-treat analysis to determine factors that may affect } \\
\text { outcome }\end{array}$ & $\begin{array}{l}\text { Increase compliance } \\
\text { with annual preventive } \\
\text { exams }\end{array}$ & $\begin{array}{l}35 \% \text { increase in screening } \\
\text { with promotora } \\
\text { intervention versus } \\
\text { postcard only }\end{array}$ \\
\hline $\begin{array}{l}\text { Jandorf et al., } \\
2014\end{array}$ & $\begin{array}{l}\text { Quasi- } \\
\text { experiment } \\
\text { al, II A }\end{array}$ & $\begin{array}{l}\text { Hispanic } \\
1968 \\
\text { participants } \\
\text { (1179 } \\
\text { intervention, } \\
789 \text { control) } \\
\end{array}$ & $\begin{array}{l}\text { Randomized breast and cervical cancer education } \\
\text { (intervention) and diabetes education (control) } \\
\text { Included navigation assistance (scheduling, language, } \\
\text { transportation, reminder calls) } \\
\text { Univariate and multivariate statistical analyses }\end{array}$ & $\begin{array}{l}\text { Greater cognitive benefit } \\
\text { leading to increased } \\
\text { screening } \\
\text { Greater acceptance of } \\
\text { navigation assistance }\end{array}$ & $\begin{array}{l}\text { Educational program alone } \\
\text { significantly increased } \\
\text { mammography }(\mathrm{OR}=2.16)\end{array}$ \\
\hline $\begin{array}{l}\text { Larkey et al., } \\
2006\end{array}$ & RCT, II B & $\begin{array}{l}\text { Hispanic } \\
\text { Low income } \\
234 \text { participants } \\
\text { in mammogram } \\
\text { arm of study }\end{array}$ & $\begin{array}{l}\text { Promotora education and social support via group } \\
\text { Focus on group identity and cohesion } \\
\text { Chi-square }\end{array}$ & $\begin{array}{l}\text { Feasibility of social } \\
\text { support-based } \\
\text { intervention } \\
\text { Effects of promotora in } \\
\text { cancer prevention and } \\
\text { screening }\end{array}$ & $\begin{array}{l}30.6 \% \text { of previously non- } \\
\text { compliant women were } \\
\text { screened by end of program }\end{array}$ \\
\hline $\begin{array}{l}\text { Larkey et al., } \\
2012\end{array}$ & RCT, I A & $\begin{array}{l}\text { Hispanic } \\
1006 \\
\text { participants } \\
\text { (604 } \\
\text { randomized to } \\
\text { group meetings, } \\
402 \text { to } \\
\text { individual } \\
\text { meeting) }\end{array}$ & $\begin{array}{l}\text { Promotora education and social support via group } \\
\text { Group vs. individual meetings } \\
\text { Stata } 10.0 \text { for screening outcomes } \\
\text { Cronbach's alpha for reliability }\end{array}$ & $\begin{array}{l}\text { Mammography } \\
\text { compliance } \\
\text { Cost }\end{array}$ & $\begin{array}{l}\text { No difference in } \\
\text { effectiveness between } \\
\text { group and individual } \\
\text { promotora sessions } \\
\text { Decreased cost with group } \\
\text { sessions } \\
\text { Significant improvement in } \\
\text { screening overall }\end{array}$ \\
\hline $\begin{array}{l}\text { Livaudais et } \\
\text { al., } 2010\end{array}$ & $\begin{array}{l}\text { Quasi- } \\
\text { experiment } \\
\text { al, II B }\end{array}$ & $\begin{array}{l}\text { Hispanic } \\
70 \text { participants }\end{array}$ & $\begin{array}{l}\text { Home parties with promotora education } \\
\text { Descriptive statistics at baseline and follow-up for general } \\
\text { cancer beliefs, screening practices, and intention } \\
\text { McNemar's test to assess significant differences }\end{array}$ & $\begin{array}{l}\text { Change in knowledge of } \\
\text { cancer and screening } \\
\text { Increased mammogram } \\
\text { intention }\end{array}$ & $\begin{array}{l}\text { Risk of cancer cannot be } \\
\text { reduced } 41 \% \text { pre } 15 \% \text { post } \\
\text { Had mammogram } 83 \% \text { pre, } \\
91 \% \text { post } \\
\text { Intention to discuss } \\
\text { mammogram with MD } 37 \% \\
\text { pre, } 67 \% \text { post }\end{array}$ \\
\hline
\end{tabular}




\begin{tabular}{|c|c|c|c|c|c|}
\hline & & & & & $\begin{array}{l}\text { Intention to have } \\
\text { mammogram } 61 \% \text { pre, } 81 \% \\
\text { post }\end{array}$ \\
\hline $\begin{array}{l}\text { Lopez et al., } \\
2006\end{array}$ & RCT, I B & $\begin{array}{l}\text { Hispanic } \\
\text { Low income } \\
447 \text { participants } \\
(283 \\
\text { intervention } \\
\text { group, } 164 \\
\text { control) }\end{array}$ & $\begin{array}{l}\text { Church-based recruitment } \\
\text { Promotora education } \\
\text { OLS hierarchical regression for continuous outcome } \\
\text { variables } \\
\text { Hierarchical logistic regression for dichotomous outcome } \\
\text { variables }\end{array}$ & $\begin{array}{l}\text { Determinants of } \\
\text { participation } \\
\text { Relationship of } \\
\text { knowledge to screening } \\
\text { behaviors }\end{array}$ & $\begin{array}{l}\text { Lower levels of } \\
\text { acculturation and greater } \\
\text { church attendance predicted } \\
\text { intervention attendance } \\
\text { Increased knowledge related } \\
\text { to increased attendance } \\
\text { Culturally sensitive health } \\
\text { promotion program } \\
\text { improves mammography } \\
\text { rates }\end{array}$ \\
\hline $\begin{array}{l}\text { Mojica et al., } \\
2016\end{array}$ & $\begin{array}{l}\text { Quasi- } \\
\text { experiment } \\
\text { al, II A }\end{array}$ & $\begin{array}{l}\text { Hispanic } \\
\text { Low income } \\
691 \text { participants }\end{array}$ & $\begin{array}{l}\text { CHW education } \\
\text { CHW navigation (scheduling, reminder calls) } \\
\text { Descriptive statistics for sociodemographic data } \\
\text { Fisher's exact or chi-square for categorical variables } \\
\text { between participants } \\
\text { Independent sample } t \text { test for continuous variables } \\
\text { McNemar's test for pre and post intervention knowledge and } \\
\text { beliefs }\end{array}$ & $\begin{array}{l}\text { Self-reported receipt of } \\
\text { mammogram } \\
\text { Knowledge of screening } \\
\text { guidelines } \\
\text { Beliefs about early } \\
\text { detection }\end{array}$ & $\begin{array}{l}\text { Improved recruitment for } \\
\text { programs } \\
\text { Improved knowledge and } \\
\text { screening }\end{array}$ \\
\hline $\begin{array}{l}\text { Navarro et al., } \\
1998\end{array}$ & RCT, I A & $\begin{array}{l}\text { Hispanic } \\
\text { Low income } \\
750 \text { participants } \\
512 \text { completed } \\
\text { survey }(27 \% \text { of } \\
\text { experimental } \\
\text { group and } 32 \% \\
\text { of control } \\
\text { group) }\end{array}$ & $\begin{array}{l}\text { Lay health workers education program } \\
\text { Takes advantage of social networks } \\
\text { Marin's short scale of acculturation } \\
\text { Social support questionnaire }\end{array}$ & $\begin{array}{l}\text { Perform self-breast exam } \\
\text { Breast exam by health } \\
\text { professional } \\
\text { Mammogram } \\
\text { compliance }\end{array}$ & $\begin{array}{l}56 \% \text { of intervention group } \\
\text { had mammogram versus } \\
44 \% \text { of control group }\end{array}$ \\
\hline $\begin{array}{l}\text { Nuno et al., } \\
2011\end{array}$ & RCT, I A & $\begin{array}{l}\text { Hispanic } \\
\text { Rural } \\
381 \text { participants } \\
(183 \\
\text { intervention, } \\
188 \text { control) } \\
\end{array}$ & $\begin{array}{l}\text { Promotora education and referral/resource information } \\
\text { Logistical regression analysis for odds ratio between } \\
\text { intervention and control group }\end{array}$ & $\begin{array}{l}\text { Effectiveness of } \\
\text { promotora educational } \\
\text { program in mammogram } \\
\text { screening }\end{array}$ & $\begin{array}{l}\text { Two times more likely to } \\
\text { have mammogram ( } 73 \% \text { vs } \\
58 \% \text { in control group) }\end{array}$ \\
\hline $\begin{array}{l}\text { Sauaia et al., } \\
2007\end{array}$ & $\begin{array}{l}\text { Quasi- } \\
\text { experiment } \\
\text { al, II A }\end{array}$ & $\begin{array}{l}\text { Hispanic and } \\
\text { non-Latina } \\
\text { Public and } \\
\text { private insured }\end{array}$ & $\begin{array}{l}\text { Welsh (2005) study repeated for insured participants } \\
\text { Church-based } \\
\text { Printed educational materials alone versus materials plus } \\
\text { promotora education }\end{array}$ & Mammogram rates & $\begin{array}{l}\text { Increase of mammogram } \\
\text { rate from } 59 \% \text { to } 61 \% \text { with } \\
\text { promotora }\end{array}$ \\
\hline
\end{tabular}




\begin{tabular}{|c|c|c|c|c|c|}
\hline & & $\begin{array}{l}8439 \\
\text { participants } \\
\text { (56\% Latinas } \\
4739 \\
\text { participants) }\end{array}$ & $\begin{array}{l}\text { Chi-square or Fisher exact test for categorical values } \\
\text { ANOVA with Welch modification for continuous variables } \\
\text { GEE parameter }\end{array}$ & & $\begin{array}{l}\text { No change with printed } \\
\text { material only } \\
\text { After adjustments, authors } \\
\text { found "significantly higher } \\
\text { increase in mammograms" } \\
\text { with promotora (GEE } 0.24 \text {, } \\
P=0.03 \text { ) }\end{array}$ \\
\hline $\begin{array}{l}\text { Scheel et al., } \\
2015\end{array}$ & $\begin{array}{l}\text { Quasi- } \\
\text { experiment } \\
\text { al, II B }\end{array}$ & $\begin{array}{l}\text { Hispanic } \\
101 \text { participants }\end{array}$ & $\begin{array}{l}\text { Home parties with promotora education and assistance with } \\
\text { scheduling mammogram } \\
\text { Bivariate analysis of variables: intention, knowledge, social } \\
\text { engagement } \\
\text { Paired } t \text { tests to evaluation pre and post intervention changes }\end{array}$ & $\begin{array}{l}\text { Increased mammography } \\
\text { intention } \\
\text { Increased knowledge of } \\
\text { breast cancer and } \\
\text { screening }\end{array}$ & $\begin{array}{l}84 \% \text { indicate } \\
\text { mammography intention } \\
\text { following intervention } \\
\text { Significant increase in } \\
\text { knowledge and social } \\
\text { engagement (more likely to } \\
\text { discuss with MD, family, } \\
\text { friends) }\end{array}$ \\
\hline $\begin{array}{l}\text { Simon et al., } \\
2019\end{array}$ & $\begin{array}{l}\text { Quasi- } \\
\text { experiment } \\
\text { al, II A }\end{array}$ & $\begin{array}{l}\text { Hispanic and } \\
\text { Black } \\
723 \text { participants } \\
\text { (69\% Hispanic) }\end{array}$ & $\begin{array}{l}\text { Helping Her Live (HHL) program test in new geographical } \\
\text { area } \\
\text { CHW follow up and navigation }\end{array}$ & $\begin{array}{l}\text { Evaluate effectiveness of } \\
\text { HHL in new area } \\
\text { Increase mammogram } \\
\text { rates } \\
\text { Increase diagnostic } \\
\text { follow up }\end{array}$ & $\begin{array}{l}74 \% \text { Hispanics sought } \\
\text { navigation } \\
360 \text { of } 723 \text { underwent } \\
\text { mammogram }(86 \% \\
\text { Hispanic) }\end{array}$ \\
\hline $\begin{array}{l}\text { Spalluto et al., } \\
2019\end{array}$ & RCT, I A & $\begin{array}{l}\text { Hispanic } \\
100 \text { participants } \\
(34 \text { control, } 33 \\
\text { group, } 33 \\
\text { individual) }\end{array}$ & $\begin{array}{l}\text { Education sessions with promotora } \\
\text { Group, individual, and control } \\
\text { R, version } 2017 \text { for randomization } \\
\text { Brief Self-Reported Health Literacy Screen (BHLS) to } \\
\text { assess health literacy and demographics and 5-point Linkert } \\
\text { scale to elicit results } \\
\text { Post mammography surveys (Patient Satisfaction with } \\
\text { Cancer Care (PSCC) measure, Interpersonal Processes of } \\
\text { Care (IPC) Survey, Patient Satisfaction with Interpersonal } \\
\text { Relationship with Navigators (PSN) measure) } \\
\text { Multivariable linear regression models examined promotora } \\
\text { versus standard of care for PSCC and IPC measures }\end{array}$ & $\begin{array}{l}\text { Satisfaction with care } \\
\text { using PSCC } \\
\text { Satisfaction with } \\
\text { promotora using PSN }\end{array}$ & $\begin{array}{l}\text { Access to promotora led to } \\
\text { higher satisfaction with care } \\
\text { No difference between } \\
\text { group versus individual } \\
\text { sessions } \\
\text { IPC shows high internal } \\
\text { consistency and reliability } \\
\text { in Hispanic population }\end{array}$ \\
\hline $\begin{array}{l}\text { Welsh et al., } \\
2005\end{array}$ & $\begin{array}{l}\text { Quasi- } \\
\text { experiment } \\
\text { al, II A }\end{array}$ & $\begin{array}{l}\text { Hispanic and } \\
\text { non-Latina } \\
\text { Medicaid } \\
\text { insured } \\
6696 \\
\text { participants }\end{array}$ & $\begin{array}{l}\text { Church-based } \\
\text { Printed educational materials alone versus materials plus } \\
\text { promotora education } \\
\text { Chi-square or Fisher exact test for categorical values } \\
\text { ANOVA with Welch modification for continuous variables }\end{array}$ & $\begin{array}{l}\text { Compliance with } \\
\text { mammography screening }\end{array}$ & $\begin{array}{l}\text { Promotora intervention } \\
\text { increased screening from } \\
25 \% \text { to } 30 \% \\
\text { Authors report this as a } \\
\text { marginally greater impact }\end{array}$ \\
\hline
\end{tabular}

Legend: BAS, Bi-Dimensional Acculturation Scale; CHW, community health worker 


\section{Appendix B}

\section{Summary of Systematic Reviews (SR)}

\begin{tabular}{|c|c|c|c|c|c|c|c|}
\hline Citation & $\begin{array}{l}\text { Quality } \\
\text { Grade }\end{array}$ & Question & Search Strategy & $\begin{array}{l}\text { Inclusion/ } \\
\text { Exclusion Criteria }\end{array}$ & $\begin{array}{l}\text { Data Extraction } \\
\text { and Analysis }\end{array}$ & Key Findings & $\begin{array}{l}\text { Usefulness/Recom } \\
\text { mendation/ } \\
\text { Implications }\end{array}$ \\
\hline $\begin{array}{l}\text { Corcoran et } \\
\text { al., } 2010\end{array}$ & $\begin{array}{l}\text { Level II } \\
\text { Qual A }\end{array}$ & $\begin{array}{l}\text { Determine } \\
\text { effectiveness of } \\
\text { interventions to } \\
\text { increase } \\
\text { mammography rates } \\
\text { in Latinas }\end{array}$ & $\begin{array}{l}\text { Databases: CINAHL, } \\
\text { Dissertation Abstracts } \\
\text { International, Gender- } \\
\text { Watch, } \\
\text { MEDLINE/PubMed, } \\
\text { PsycINFO } \\
\text { No restriction on start } \\
\text { date until January } \\
2009 \\
\text { Search terms: } \\
\text { Latina/Hispanic, } \\
\text { mammogram/breast } \\
\text { cancer, } \\
\text { prevent/intervention, } \\
\text { promote/encourage }\end{array}$ & $\begin{array}{l}\text { Experimental or } \\
\text { quasi-experimental } \\
\text { Control or } \\
\text { comparison } \\
\text { intervention used } \\
\text { Improve } \\
\text { mammography } \\
\text { rates } \\
\text { Latina, living in } \\
\text { U.S. }\end{array}$ & $\begin{array}{l}9 \text { of } 52 \text { studies met } \\
\text { criteria } \\
\text { Fail-safe to } \\
\text { determine number } \\
\text { of undiscovered or } \\
\text { unpublished studies } \\
\text { Odds ratios were } \\
\text { converted to } \\
\text { Cohen's } d \\
\text { Heterogeneity } \\
\text { analyzed with } \\
\text { Corcoran's } Q \\
\text { Statistical } \\
\text { significance defined } \\
\text { as } p<0.10\end{array}$ & $\begin{array}{l}\text { All } 9 \text { studies } \\
\text { included both a } \\
\text { cultural and } \\
\text { educational } \\
\text { component of } \\
\text { promotora } \\
\text { intervention } \\
\text { Most common was } \\
\text { promotora } \\
\text { intervention (5 } \\
\text { studies) } \\
1 \text { study increased } \\
\text { access to } \\
\text { mammography }\end{array}$ & $\begin{array}{l}\text { Most effective } \\
\text { model included } \\
\text { free mammograms } \\
\text { Too few studies to } \\
\text { test effectiveness } \\
\text { of intervention type } \\
\text { Studies included in } \\
\text { the evidence table } \\
\text { in Appendix A: } \\
\text { Fernandez et al., } \\
\text { 2008; Navarro et } \\
\text { al., 1998; Sauaia et } \\
\text { al., 2007 }\end{array}$ \\
\hline $\begin{array}{l}\text { Luque et al., } \\
2019\end{array}$ & $\begin{array}{l}\text { Level II } \\
\text { Qual. A }\end{array}$ & $\begin{array}{l}\text { Educational } \\
\text { interventions to } \\
\text { increase } \\
\text { mammography } \\
\text { screening in Hispanic } \\
\text { women }\end{array}$ & $\begin{array}{l}\text { Databases: Scopus, } \\
\text { PubMed, ESBSO- } \\
\text { Host } \\
\text { Boolean MeSH } \\
\text { keywords: } \\
\text { Hispanic/Latina AND } \\
\text { woman/women AND } \\
\text { breast } \\
\text { cancer/mammogram/b } \\
\text { reast screening AND } \\
\text { intervention/program } \\
\text { May } 2003 \text { to } \\
\text { September } 2017 \\
\text { Experimental or } \\
\text { quasi-experimental } \\
\text { studies }\end{array}$ & $\begin{array}{l}\text { At least } 50 \% \text { of } \\
\text { participants } \\
\text { Hispanic } \\
\text { Mammography } \\
\text { screening reported } \\
\text { separately } \\
\text { Comparison group } \\
\text { must be present } \\
\text { Excluded } \\
\text { mammography } \\
\text { intention } \\
\text { Excluded if outside } \\
\text { of the U.S. }\end{array}$ & $\begin{array}{l}5 \text { of } 269 \text { studies met } \\
\text { criteria } \\
\text { Odds ratio used to } \\
\text { calculate } \\
\text { intervention } \\
\text { effectiveness } \\
\text { Cochran's Q } \\
\text { statistic with } p< \\
0.05 \text { for study } \\
\text { heterogeneity } \\
\text { Higgins } I^{2} \text { index for } \\
\text { degree of } \\
\text { inconsistency } \\
\text { Publication bias } \\
\text { assessed with funnel } \\
\text { plots }\end{array}$ & $\begin{array}{l}\text { All } 5 \text { studies } \\
\text { included } \\
\text { promotora-led } \\
\text { education } \\
\text { Odds ratio between } \\
1.02 \text { and } 2.18 \\
\text { Hispanics have } \\
\text { lower compliance } \\
\text { rate for } \\
\text { mammography } \\
\text { Promotoras may } \\
\text { help mediate } \\
\text { impact of barriers } \\
\text { to mammography }\end{array}$ & $\begin{array}{l}\text { Promotoras may } \\
\text { help lessen impact } \\
\text { of low health } \\
\text { literacy, knowledge } \\
\text { deficits, and low } \\
\text { awareness of } \\
\text { availability of } \\
\text { screening services } \\
\text { All } 5 \text { studies } \\
\text { included in the } \\
\text { evidence table in } \\
\text { Appendix A } \\
\text { (Coronado et al., } \\
\text { 2016; Elder et al., } \\
\text { 2017; Fernandez et } \\
\text { al., 2009; Jandorf }\end{array}$ \\
\hline
\end{tabular}




\begin{tabular}{|c|c|c|c|c|c|c|c|}
\hline & & & $\begin{array}{l}\text { Peer reviewed and } \\
\text { published in scientific } \\
\text { journals }\end{array}$ & & & & $\begin{array}{l}\text { et al., 2014; Nuno } \\
\text { et al., 2011) }\end{array}$ \\
\hline $\begin{array}{l}\text { Martinez- } \\
\text { Donate, } 2009\end{array}$ & $\begin{array}{l}\text { Level II } \\
\text { Qual. A }\end{array}$ & $\begin{array}{l}\text { Does the use of LHAs } \\
\text { promote breast and/or } \\
\text { cervical cancer } \\
\text { screening in Latinas }\end{array}$ & $\begin{array}{l}\text { PubMed } \\
\text { Inception through } \\
2008 \\
\text { Boolean MeSH } \\
\text { keywords: Hispanic } \\
\text { Americans, } \\
\text { community health } \\
\text { aides, vaginal smears, } \\
\text { uterine neoplasms, } \\
\text { mammography, breast } \\
\text { neoplasms, breast self- } \\
\text { examination, breast, } \\
\text { physical examination, } \\
\text { diagnostic tests, } \\
\text { routine, health } \\
\text { promotion }\end{array}$ & $\begin{array}{l}\text { Promotion of } \\
\text { screening for breast } \\
\text { and/or cervical } \\
\text { cancer } \\
\text { Latina population } \\
\text { Used LHAs as part } \\
\text { of intervention } \\
\text { Included process, } \\
\text { impact, or outcome } \\
\text { data }\end{array}$ & $\begin{array}{l}14 \text { of } 134 \text { studies } \\
\text { met criteria } \\
11 \text { targeted both } \\
\text { breast and cervical } \\
\text { screening } \\
9 \text { focused on low- } \\
\text { income Latinas } \\
12 \text { involved LHA } \\
\text { outreach } \\
5 \text { were experimental } \\
\text { or quasi- } \\
\text { experimental }\end{array}$ & $\begin{array}{l}5 \text { experimental and } \\
\text { quasi-experimental } \\
\text { studies evaluated } \\
2 \text { found no } \\
\text { significant effects } \\
1 \text { found increased } \\
\text { Pap smear rates } \\
1 \text { found significant } \\
\text { effects on } \\
\text { mammogram rates } \\
1 \text { found } \\
\text { intervention was } \\
\text { more effective for } \\
\text { Latina versus. Non- } \\
\text { Latina }\end{array}$ & $\begin{array}{l}7 \text { of the } 14 \text { studies } \\
\text { are included in the } \\
\text { evidence table in } \\
\text { Appendix A } \\
\text { (Hansen et al., } \\
\text { 2005; Hunter et al., } \\
\text { 2004; Larkey et al., } \\
\text { 2006; Lopez et al., } \\
\text { 2006; Navarro et } \\
\text { al., 1998; Sauaia et } \\
\text { al., 2007; Welsh et } \\
\text { al., 2005) } \\
2 \text { studies found } \\
\text { evidence of } \\
\text { effectiveness } \\
\text { More research } \\
\text { needed }\end{array}$ \\
\hline
\end{tabular}

Legend: LHA, lay health advisor 


\section{Appendix C}

Summary of Studies on the Use of Promotoras to Improve Mammography Rates Among Hispanic Women

\begin{tabular}{|c|c|c|c|c|c|c|c|c|c|c|c|c|c|c|c|c|c|c|}
\hline Study & $\begin{array}{l}\text { Larkey } \\
\text { et al., } \\
2012\end{array}$ & $\begin{array}{l}\text { Spalluto } \\
\text { et al., } \\
2019\end{array}$ & $\begin{array}{l}\text { Scheel } \\
\text { et al., } \\
2015\end{array}$ & $\begin{array}{l}\text { Mojica } \\
\text { et al., } \\
2016\end{array}$ & $\begin{array}{l}\text { Livaudais } \\
\text { et al., } \\
2010\end{array}$ & $\begin{array}{l}\text { Simon } \\
\text { et al., } \\
2019\end{array}$ & $\begin{array}{l}\text { Navarro } \\
\text { et al., } \\
1998\end{array}$ & $\begin{array}{l}\text { Lopez } \\
\text { et al., } \\
2006\end{array}$ & $\begin{array}{l}\text { Hunter } \\
\text { et al., } \\
2004\end{array}$ & $\begin{array}{l}\text { Welsh } \\
\text { et al., } \\
2005\end{array}$ & $\begin{array}{l}\text { Sauaia } \\
\text { et al., } \\
2007\end{array}$ & $\begin{array}{l}\text { Larkey } \\
\text { et al., } \\
2006\end{array}$ & $\begin{array}{l}\text { Hansen } \\
\text { et al., } \\
2005\end{array}$ & $\begin{array}{l}\text { Elder } \\
\text { et al., } \\
2017\end{array}$ & $\begin{array}{l}\text { Nuño } \\
\text { et al., } \\
2011\end{array}$ & $\begin{array}{l}\text { Jandorf } \\
\text { et al., } \\
2014\end{array}$ & $\begin{array}{l}\text { Fernandez } \\
\text { et al., } \\
2009\end{array}$ & $\begin{array}{l}\text { Coronado } \\
\text { et al., } \\
2016\end{array}$ \\
\hline $\begin{array}{l}\text { Region } \\
\text { East } \\
\text { Southwest } \\
\text { Midwest } \\
\text { West } \\
\text { South } \\
\end{array}$ & $\mathrm{X}$ & $\mathrm{X}$ & $\mathrm{X}$ & $\mathrm{X}$ & $\mathrm{X}$ & $\mathrm{X}$ & $\mathrm{X}$ & $\mathrm{X}$ & $\mathrm{X}$ & $\mathrm{X}$ & $\mathrm{X}$ & $\mathrm{X}$ & $\mathrm{X}$ & $\mathrm{X}$ & $\mathrm{X}$ & $\mathrm{X}$ & $\mathrm{X}$ & $\mathrm{X}$ \\
\hline $\begin{array}{l}\text { Intervention } \\
\text { Promotora } \\
\text { Navigation } \\
\text { Education } \\
\text { Individual } \\
\text { Group } \\
\text { Community event } \\
\text { Phone calls } \\
\text { Home visits } \\
\text { Social support } \\
\end{array}$ & $\begin{array}{l}X \\
X \\
X \\
X\end{array}$ & $\begin{array}{l}X \\
X \\
X \\
X\end{array}$ & $\begin{array}{l}\mathrm{X} \\
\mathrm{X} \\
\mathrm{X} \\
\\
\mathrm{X} \\
\mathrm{X}\end{array}$ & $\begin{array}{l}X \\
X \\
X\end{array}$ & $\begin{array}{l}\mathrm{X} \\
\mathrm{X} \\
\mathrm{X} \\
\mathrm{X} \\
\mathrm{X} \\
\end{array}$ & $\begin{array}{l}X \\
X \\
\\
X \\
X \\
X\end{array}$ & $\begin{array}{l}X \\
X\end{array}$ & $\begin{array}{l}X \\
X\end{array}$ & $\begin{array}{l}X \\
X \\
X \\
X\end{array}$ & $\begin{array}{l}X \\
X \\
X \\
X \\
X\end{array}$ & $\begin{array}{l}X \\
X \\
X \\
X \\
X\end{array}$ & $\begin{array}{l}X \\
X \\
X \\
\\
X \\
\end{array}$ & $\begin{array}{l}X \\
X \\
X \\
X \\
X \\
X \\
X\end{array}$ & $\begin{array}{l}X \\
X \\
X \\
X \\
X \\
X \\
X \\
X \\
\end{array}$ & $\begin{array}{l}X \\
X \\
X \\
X\end{array}$ & $\begin{array}{l}X \\
X \\
X \\
X \\
X \\
X \\
\\
X \\
X \\
\end{array}$ & $\begin{array}{l}X \\
X \\
X \\
X \\
\\
X \\
X\end{array}$ & $\begin{array}{l}X \\
X \\
X \\
X\end{array}$ \\
\hline Hispanic women & $\mathrm{X}$ & $\mathrm{X}$ & $\mathrm{X}$ & $\mathrm{X}$ & $\mathrm{X}$ & $\mathrm{X}$ & $\mathrm{X}$ & $\mathrm{X}$ & $\mathrm{X}$ & $\mathrm{X}$ & $\mathrm{X}$ & $\mathrm{X}$ & $\mathrm{X}$ & $\mathrm{X}$ & $\mathrm{X}$ & $\mathrm{X}$ & $\mathrm{X}$ & $\mathrm{X}$ \\
\hline $\begin{array}{l}\text { Low income/(un) } \\
\text { under-insured }\end{array}$ & $\mathrm{X}$ & & $\mathrm{X}$ & $\mathrm{X}$ & & $\mathrm{X}$ & $\mathrm{X}$ & $\mathrm{X}$ & $\mathrm{X}$ & $\mathrm{X}$ & & $\mathrm{X}$ & & & & & $\mathrm{X}$ & \\
\hline Age 40 or older & $\mathrm{X}$ & $\mathrm{X}$ & $\mathrm{X}$ & $\mathrm{X}$ & $\mathrm{X}$ & $\mathrm{X}$ & & $\mathrm{X}$ & $\mathrm{X}$ & & & $\mathrm{X}$ & & $\mathrm{X}$ & & $\mathrm{X}$ & & \\
\hline $\begin{array}{l}\text { Outcome } \\
\text { MS } \\
\text { MI } \\
\text { Knowledge } \\
\text { Care satisfaction } \\
\text { Cost } \\
\end{array}$ & $\mathrm{X}$ & $\mathrm{X}$ & $\begin{array}{l}X \\
X\end{array}$ & $\begin{array}{l}X \\
X\end{array}$ & $\begin{array}{l}X \\
X \\
X\end{array}$ & $\mathrm{X}$ & $\mathrm{X}$ & $\begin{array}{l}X \\
X\end{array}$ & $\mathrm{X}$ & $\mathrm{X}$ & $\mathrm{X}$ & $X$ & $\mathrm{X}$ & $\begin{array}{l}X \\
X\end{array}$ & $\mathrm{X}$ & $\mathrm{X}$ & $\begin{array}{l}X \\
X\end{array}$ & $\begin{array}{l}X \\
X\end{array}$ \\
\hline $\begin{array}{l}\text { Results for MS } \\
\text { Significant effect } \\
\text { No effect }\end{array}$ & $\mathrm{X}$ & & & $\mathrm{X}$ & $\mathrm{X}$ & $\mathrm{X}$ & $\mathrm{X}$ & $\mathrm{X}$ & $\mathrm{X}$ & $\mathrm{X}$ & $\mathrm{X}$ & $\mathrm{X}$ & $\mathrm{X}$ & $\mathrm{X}$ & $\mathrm{X}$ & $\mathrm{X}$ & $\mathrm{X}$ & $\mathrm{X}$ \\
\hline
\end{tabular}

Legend: MS, mammography; MI, Mammography intention 
Appendix D

Project Schedule

\begin{tabular}{|c|c|c|c|c|c|c|c|c|c|c|c|c|c|c|c|c|}
\hline \multirow[b]{2}{*}{ 龸 } & \multicolumn{8}{|c|}{ NUR7802 } & \multicolumn{8}{|c|}{ NUR7803 } \\
\hline & $\begin{array}{l}\bar{y} \\
\frac{1}{2} \\
3\end{array}$ & $\frac{n}{\frac{y}{d}}$ & $\begin{array}{l}n \\
\frac{y}{8} \\
3\end{array}$ & $\frac{\pi}{\frac{d}{8}}$ & $\begin{array}{l}a \\
\frac{a}{d} \\
\frac{d}{3}\end{array}$ & $\begin{array}{l}= \\
\bar{y} \\
3 \\
3\end{array}$ & $\frac{n}{\frac{y}{d}}$ & $\begin{array}{l}n \\
\frac{y}{d} \\
\frac{d}{3}\end{array}$ & $\frac{\bar{y}}{3}$ & $\begin{array}{l}m \\
\frac{y}{d} \\
3\end{array}$ & $\begin{array}{l}n \\
y \\
z \\
z\end{array}$ & $\begin{array}{l}\bar{y} \\
\frac{u}{d} \\
z\end{array}$ & $\begin{array}{l}\frac{a}{y} \\
\frac{d}{3}\end{array}$ & $\begin{array}{l}= \\
\bar{y} \\
3 \\
3\end{array}$ & $\begin{array}{l}\frac{n}{y} \\
\frac{y}{d} \\
\frac{d}{3}\end{array}$ & $\begin{array}{l}n \\
\frac{n}{d} \\
0 \\
3\end{array}$ \\
\hline & $\Xi$ & $\stackrel{n}{s}$ & $\frac{\infty}{\lambda}$ & $\stackrel{\text { ป }}{\text { ป }}$ & $\frac{\infty}{m}$ & $\underset{n}{N}$ & $\frac{n}{f}$ & $\stackrel{\rho}{\frac{\gamma}{\gamma}}$ & $\stackrel{0}{\frac{1}{n}}$ & 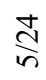 & $\frac{1}{\delta}$ & $\bar{d}$ & $\frac{n}{r}$ & $\stackrel{\circ}{\stackrel{2}{2}}$ & $\underset{\infty}{\infty}$ & $\frac{n}{\infty}$ \\
\hline $\begin{array}{l}\text { Submit proposal for } \\
\text { EPRC review }\end{array}$ & & $\mathrm{X}$ & & & & & & & & & & & & & & \\
\hline Obtain EPRC approval & & & $\mathrm{X}$ & & & & & & & & & & & & & \\
\hline Budget approval & & & & $\mathrm{X}$ & & & & & & & & & & & & \\
\hline Collect baseline data & & & & & $\mathrm{X}$ & $\mathrm{X}$ & $\mathrm{X}$ & & & & & & & & & \\
\hline $\begin{array}{l}\text { Staff information } \\
\text { sessions }\end{array}$ & & & & & $\mathrm{X}$ & $\mathrm{X}$ & & & & & & & & & & \\
\hline $\begin{array}{l}\text { Implement } \\
\text { intervention }\end{array}$ & & & & & & $\mathrm{X}$ & $\mathrm{X}$ & $\mathrm{X}$ & $\mathrm{X}$ & & & & & & & \\
\hline Conclude intervention & & & & & & & & & $\mathrm{X}$ & & & & & & & \\
\hline Data analysis & & & & & & & & & $\mathrm{X}$ & $\mathrm{X}$ & & & & & & \\
\hline $\begin{array}{l}\text { Complete summary of } \\
\text { findings }\end{array}$ & & & & & & & & & & $\mathrm{X}$ & & & & & & \\
\hline $\begin{array}{l}\text { Final report to } \\
\text { stakeholders }\end{array}$ & & & & & & & & & & & & $\mathrm{X}$ & & & & \\
\hline Plan for sustainability & & & & & & & & & & & & $\mathrm{X}$ & $\mathrm{X}$ & & & \\
\hline Disseminate findings & & & & & & & & & & & & & & $\mathrm{X}$ & $\mathrm{X}$ & \\
\hline
\end{tabular}


Appendix E

Project Intervention Schedule

\begin{tabular}{|c|c|c|c|c|c|c|c|c|c|c|c|c|c|c|c|c|}
\hline \multirow[b]{2}{*}{ 忘 } & \multicolumn{8}{|c|}{ NUR7802 } & \multicolumn{8}{|c|}{ NUR7803 } \\
\hline & $\begin{array}{l}-\bar{y} \\
\frac{y}{0} \\
\frac{0}{3}\end{array}$ & $\begin{array}{l}m \\
\frac{1}{0} \\
\stackrel{D}{3}\end{array}$ & $\begin{array}{l}n \\
\frac{\pi}{0} \\
\stackrel{0}{3}\end{array}$ & $\frac{\sqrt{y}}{\frac{1}{0}}$ & $\begin{array}{l}a \\
\frac{y}{0} \\
3\end{array}$ & $\begin{array}{l}\text { 二 } \\
\frac{y}{8} \\
\dot{0} \\
3\end{array}$ & $\frac{n}{\frac{n}{0}}$ & $\frac{n}{\frac{n}{8}}$ & $\frac{\bar{y}}{\frac{y}{0}}$ & $\begin{array}{l}m \\
\frac{n}{8} \\
\frac{d}{3}\end{array}$ & $\begin{array}{l}n \\
\frac{n}{0} \\
3 \\
3\end{array}$ & $\frac{\sqrt{4}}{\frac{0}{0}}$ & $\begin{array}{l}a \\
\frac{y}{0} \\
3\end{array}$ & $\begin{array}{l}= \\
\frac{y}{8} \\
\frac{0}{3}\end{array}$ & $\begin{array}{l}\frac{m}{y} \\
\frac{y}{0} \\
\frac{0}{3}\end{array}$ & $\begin{array}{l}\frac{n}{2} \\
\frac{\pi}{d} \\
3\end{array}$ \\
\hline & $\Xi$ & $\stackrel{n}{\stackrel{n}{c}}$ & $\frac{\infty}{\lambda}$ & 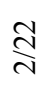 & $\frac{\infty}{n}$ & 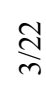 & $\stackrel{n}{\gamma}$ & $\stackrel{\partial}{\gamma}$ & $\frac{0}{n}$ & $\underset{⿱ 丶}{\stackrel{\Delta}{N}}$ & $\frac{\kappa}{\sigma}$ & $\overrightarrow{\mathrm{d}}$ & $\frac{n}{r}$ & $\stackrel{9}{\stackrel{2}{1}}$ & $\frac{N}{\infty}$ & $\frac{n}{\infty}$ \\
\hline $\begin{array}{l}\text { Staff information } \\
\text { session }\end{array}$ & & & & & $X$ & $\mathrm{X}$ & & & & & & & & & & \\
\hline $\begin{array}{l}\text { Promotora information } \\
\text { session }\end{array}$ & & & & & $\mathrm{X}$ & $\mathrm{X}$ & & & & & & & & & & \\
\hline $\begin{array}{l}\text { Evaluate promotora } \\
\text { performance }\end{array}$ & & & & & & $\mathrm{X}$ & $\mathrm{X}$ & $\mathrm{X}$ & $\mathrm{X}$ & & & & & & & \\
\hline $\begin{array}{l}\text { Gather data: number } \\
\text { of orders, promotora } \\
\text { outreach, participant } \\
\text { scheduled } \\
\text { mammogram, } \\
\text { participant obtained } \\
\text { mammogram }\end{array}$ & & & & & & $X$ & $\mathrm{X}$ & $\mathrm{X}$ & $\mathrm{X}$ & & & & & & & \\
\hline $\begin{array}{l}\text { Provide feedback to } \\
\text { promotora }\end{array}$ & & & & & & $\mathrm{X}$ & $\mathrm{X}$ & $\mathrm{X}$ & $X$ & & & & & & & \\
\hline $\begin{array}{l}\text { Staff meeting for } \\
\text { feedback }\end{array}$ & & & & & & $\mathrm{X}$ & $\mathrm{X}$ & $\mathrm{X}$ & $X$ & & & & & & & \\
\hline
\end{tabular}




\section{Appendix F}

Budget

\section{EXPENSES}

\section{REVENUE}

\begin{tabular}{|c|c|c|c|}
\hline \multicolumn{2}{|l|}{ Direct } & \multirow{2}{*}{$\begin{array}{l}\text { Billing } \\
\text { Grants }\end{array}$} & \multirow{2}{*}{$\begin{array}{l}\$ 0 \\
\$ 0\end{array}$} \\
\hline Salary & $\$ 1360$ & & \\
\hline $\begin{array}{ll}\text { - } & \text { Promotora intervention } \\
& \text { salary } \$ 160 \\
\text { - } & \text { Staff salary (meetings, } \\
\text { intervention) } \$ 1200\end{array}$ & & & \\
\hline Supplies & $\$ 25$ & Institutional budget support & $\$ 0$ \\
\hline Services & $\$ 0$ & & \\
\hline Statistician & $\$ 99$ & & \\
\hline \multicolumn{4}{|l|}{ Indirect } \\
\hline Overhead & $\$ 0$ & & \\
\hline Travel expenses ( 57.5 cents/mile) & $\$ 427.80$ & & \\
\hline Total Expenses & $\$ 1911.80$ & Total Revenue & $\$ 0$ \\
\hline Net Balance & & & $-\$ 1911.80$ \\
\hline
\end{tabular}




\section{Appendix G}

\section{Data Collection Tool}

\begin{tabular}{|c|c|c|c|c|c|c|c|c|}
\hline $\begin{array}{l}\text { Participant } \\
\#\end{array}$ & Age & $\begin{array}{l}\text { Gender } \\
(\mathrm{M} / \mathrm{F} / \mathbf{O})\end{array}$ & $\begin{array}{c}\text { Ethnicity } \\
\text { (H/C/AA/A/O) }\end{array}$ & $\begin{array}{l}\text { Date Rx } \\
\text { Mammo }\end{array}$ & $\begin{array}{l}\text { Scheduled } \\
\text { Mammo }\end{array}$ & $\begin{array}{l}\text { Completed } \\
\text { Mammo }\end{array}$ & $\begin{array}{l}\text { Promotora } \\
\text { Contact } \\
(\mathbf{Y}, \mathbf{N})\end{array}$ & Promotora Notes \\
\hline 01 & 46 & $\mathrm{~F}$ & $\mathrm{H}$ & $03 / 15 / 2021$ & & $\mathrm{X}$ & $\mathrm{Y}$ & Completed mammogram \\
\hline 02 & 63 & $\mathrm{~F}$ & $\mathrm{H}$ & $03 / 19 / 2021$ & & $\mathrm{X}$ & $\mathrm{Y}$ & $\begin{array}{l}\text { Completed mammogram, assisted in obtaining } \\
\text { results }\end{array}$ \\
\hline 03 & 51 & $\mathrm{~F}$ & $\mathrm{H}$ & $04 / 02 / 2021$ & & $\mathrm{X}$ & $\mathrm{Y}$ & Completed mammogram \\
\hline 04 & 52 & $\mathrm{~F}$ & $\mathrm{H}$ & $04 / 09 / 2021$ & $\mathrm{X}$ & & $Y$ & $\begin{array}{l}\text { Assisted with navigation, mammogram } \\
\text { scheduled }\end{array}$ \\
\hline 05 & 57 & $\mathrm{~F}$ & $\mathrm{H}$ & $04 / 09 / 2021$ & $\mathrm{X}$ & & $\mathrm{Y}$ & $\begin{array}{l}\text { Assisted with navigation, mammogram } \\
\text { scheduled }\end{array}$ \\
\hline 06 & 40 & $\mathrm{~F}$ & $\mathrm{H}$ & $04 / 13 / 2021$ & $\mathrm{X}$ & & $\mathrm{Y}$ & $\begin{array}{l}\text { Education and support provided, assisted with } \\
\text { navigation, mammogram scheduled }\end{array}$ \\
\hline 07 & 44 & $\mathrm{~F}$ & $\mathrm{H}$ & $04 / 13 / 2021$ & & $\mathrm{X}$ & $Y$ & $\begin{array}{l}\text { Assisted with navigation, mammogram } \\
\text { completed }\end{array}$ \\
\hline 08 & 46 & $\mathrm{~F}$ & $\mathrm{H}$ & $04 / 14 / 2021$ & $\mathrm{X}$ & & $\mathrm{Y}$ & $\begin{array}{l}\text { Assisted with navigation, mammogram } \\
\text { scheduled }\end{array}$ \\
\hline 09 & 51 & $\mathrm{~F}$ & $\mathrm{H}$ & $05 / 03 / 2021$ & $X$ & & $\mathrm{Y}$ & $\begin{array}{l}\text { Assisted with navigation, mammogram } \\
\text { scheduled }\end{array}$ \\
\hline 10 & 56 & $\mathrm{~F}$ & $\mathrm{H}$ & $05 / 04 / 2021$ & $\mathrm{X}$ & & $\mathrm{Y}$ & Mammogram scheduled \\
\hline 11 & 65 & $\mathrm{~F}$ & $\mathrm{H}$ & $05 / 07 / 2021$ & $\mathrm{X}$ & & $\mathrm{Y}$ & Mammogram scheduled \\
\hline
\end{tabular}

Legend: $\mathrm{M}=$ Male, $\mathrm{F}=$ Female, $\mathrm{H}=$ Hispanic, $\mathrm{C}=$ Caucasian, $\mathrm{AA}=$ African American, $\mathrm{A}=\mathrm{Asian}, \mathrm{O}=\mathrm{Other}$ (specify) 


\section{Appendix H}

\section{Comparison Data}

\begin{tabular}{|c|c|c|c|}
\hline Measures & Baseline & $\begin{array}{c}\text { Goal } \\
\text { Week } 8\end{array}$ & $\begin{array}{l}\text { Outcome } \\
\text { Week } 8\end{array}$ \\
\hline \multicolumn{4}{|l|}{ Outcome } \\
\hline Completion or scheduling of mammogram & $73 \%$ & $\uparrow 20 \%$ & $\uparrow 37 \%$ \\
\hline \multicolumn{4}{|l|}{ Process } \\
\hline Eligible patients ordered mammogram & $\mathrm{X}$ & $\geq 95 \%$ & $85 \%$ \\
\hline Called by promotora & NA & $\geq 95 \%$ & $100 \%$ \\
\hline \multicolumn{4}{|l|}{ Balancing } \\
\hline Promotora time for intervention in hours & NA & NA & 16 \\
\hline Other staff time for intervention in hours & NA & NA & 4 \\
\hline \multicolumn{4}{|l|}{ Financial } \\
\hline Promotora cost for intervention ( $\$ 10.00 /$ hour $)$ & NA & NA & $\$ 160$ \\
\hline Other staff cost for intervention (est. $\$ 300 /$ hour) & NA & NA & $\$ 1200$ \\
\hline \multicolumn{4}{|l|}{ Sustainability } \\
\hline $\begin{array}{l}\text { Estimated cost (per } 100 \text { screened) of treating breast cancer diagnosed at } \\
\text { Stage } 1\end{array}$ & $\geq \$ 450,000$ & NA & NA \\
\hline $\begin{array}{l}\text { Estimated cost (per } 100 \text { screened) of treating breast cancer diagnosed at } \\
\text { Stage } 2\end{array}$ & $\geq \$ 280,000$ & NA & NA \\
\hline $\begin{array}{l}\text { Estimated cost (per } 100 \text { screened) of treating breast cancer diagnosed at } \\
\text { Stage } 3\end{array}$ & $\geq \$ 232,000$ & NA & NA \\
\hline $\begin{array}{l}\text { Estimated cost (per } 100 \text { screened) of treating breast cancer diagnosed at } \\
\text { Stage } 4\end{array}$ & $\geq \$ 186,000$ & NA & NA \\
\hline $\begin{array}{l}\text { Estimated cost of staff to sustain intervention (promotora calls } 2 \\
\text { hours/week) }\end{array}$ & $\$ 20$ & NA & NA \\
\hline
\end{tabular}

